\title{
BUSIER Than EVER? A DATA-Driven ASSESSMENT AND FORECAST OF WTO CASELOAD $^{\mathrm{a}}$
}

\section{Joost Pauwelyn and Weiwei Zhang ${ }^{\mathrm{b}}$}

30 April 2018

\begin{abstract}
Conventional wisdom has it that, in recent years, the legalized mechanism of dispute settlement before the World Trade Organization (WTO) has been "busier than ever", "a victim of its own success". This paper uses count data to assess the WTO's current caseload and examines how it has evolved since the WTO's creation in 1995. We also forecast panel and Appellate Body (AB) caseload ten years from now using different scenarios.
\end{abstract}

WTO dispute settlement does, indeed, currently experience a peak in terms of the total number of cases pending before panels and the $A B$ (as of 30 April 2018, respectively, 18 and 8). However, this is not due to an increase in new cases filed (new consultation requests markedly reduced, from a high of 50 in 1997 to "only" 17 in 2017), but rather because pending cases take much longer to conclude as they have become more complex and are often delayed for lack of human resources. In addition, fewer cases filed get formally settled (from $20 \%$ in the first five years of the WTO to almost zero after 2014), appeal rates remain very high (on average 68\%), and the share of followup disputes over compliance (DSU Art. 21.5) has markedly increased, all three factors leading to more (pending) caseload without actually more (new) cases filed, or more panel or AB reports issued (the number of reports produced per year has actually gone down, dropping from a peak of 26 panel reports and 13 AB reports in 2000, to "only" 13 panel reports and 6 Appellate Body reports in 2017).

\footnotetext{
${ }^{a}$ This paper was made possible thanks to funding from the Swiss National Science Foundation (SNF) in the context of the Project "Convergence versus Divergence? Text-as-data and Network Analysis of International Economic Law Treaties and Tribunals".

${ }^{\mathrm{b}}$ Respectively, Professor and Post-Doc Researcher, Graduate Institute of International and Development Studies, Geneva. Thanks to Theresa Carpenter for help with the forecasting and to Wolfgang Aschner and Kseniia Tumasova for their assistance in data collection.
} 
WTO dispute settlement is also predominantly used (i) for certain types of disputes (45\% of cases filed between 2012-2016 are trade remedy disputes, compared to only $23 \%$ between $1995-1999$ ) and (ii) for disputes between a small subset of WTO members (20 WTO Members represent $85 \%$ of DSU participation as main party).

Looking forward, we forecast that the current glut in WTO caseload will not last. More specifically, after a temporary drop in 2019, we forecast a record-breaking spike in 2020-2022, after which WTO caseload will fall back and stabilize at numbers we have seen before. In none of the three scenarios we set out ("business as usual", "back to normal", "more settlements, less appeals") is there reason to panic today (e.g. to massively hire additional, long-term WTO Secretariat staff; temporary hires to address the 2020-2022 spike would suffice). Moreover, relatively small improvements -- panels and the $A B$ renewing compliance with timeframes set out in the DSU; the system improving on its "clearly preferred" solution of settlement, and parties exercising restraint when it comes to appealing panel reports (the assumptions under our "more settlements, less appeals scenario") -- would bring WTO caseload down to surprisingly low levels (post-2021: 6-7 concurrent panels, and 1-2 concurrent AB proceedings). But there is also a "worst case scenario": if WTO Members continue to fail to fill vacancies on the Appellate Body, WTO dispute settlement will grind to a halt in December 2019, at which time only 1 individual would remain on the $A B$, making it impossible for the $A B$ to function.

\section{CENTRE For TRADE AND ECONOMIC INTEGRATION (CTEI)}

The Centre for Trade and Economic Integration fosters world-class multidisciplinary scholarship aimed at developing solutions to problems facing the international trade system and economic integration more generally. It works in association with public sector and private sector actors, giving special prominence to Geneva-based International Organisations such as the WTO and UNCTAD. The Centre also bridges gaps between the scholarly and policymaking communities through outreach and training activities in Geneva.

\section{www.graduateinstitute.ch/ctei}




\section{Introduction}

Among WTO stakeholders in Geneva, there is a sense that WTO dispute settlement is busier than ever, a victim of its own success. Roberto Azevêdo, the Director-General (DG) of the WTO stated in February 2017 that the dispute settlement system "is in higher demand than ever" and indicated that the "huge caseload" may not be sustainable. ${ }^{3}$ He also cautioned that there is no spare capacity to respond to any future rise in cases. ${ }^{4}$ The caseload already caught the DG's attention in 2015, when he felt it "extremely unlikely" that the "high volume of casework is just a temporary surge" and tried to seek solutions. ${ }^{5}$ The then chairman of the Appellate Body (AB) Thomas Graham, in November 2016, also spoke of a "tsunami" of appeals. ${ }^{6}$

WTO Members are experiencing the impact of this caseload. Firstly, since 2015 many WTO litigants have been suffering from unprecedented delays in panel proceedings, especially after panel composition. ${ }^{7}$ In the six disputes for which a panel was composed between December 2014 and December 2015, the panel in each of the six cases circulated a communication to the parties after the panel was composed, informing them that "the beginning of the Panel's work has been delayed as a result of a lack of available experienced lawyers in the Secretariat." ${ }^{8}$ The delay caused by the lack of staff in the WTO Secretariat to support the panels was in the spotlight of discussions at various Dispute Settlement Body (DSB) meetings in 2015. ${ }^{9}$ At least part of the reason was attributed to "the large volume of disputes currently in the system". ${ }^{10}$

Secondly, the Appellate Body as well has experienced serious delays and has been struggling to meet the prescribed 90-days deadline to circulate its reports. The Dispute Settlement Understanding (DSU) provides that the proceedings before the Appellate Body shall "in no case" exceed 90 days from the date a party formally notifies its decision to

\footnotetext{
${ }^{3}$ See WTO website: https://www.wto.org/english/news_e/spra_e/spra158_e.htm (last visited 6 April 2018)

${ }^{4}$ Ibid.

${ }^{5}$ See WTO website: https://www.wto.org/english/news_e/spra_e/spra94_e.htm (last visited 6 April 2018)

${ }^{6}$ Thomas Graham, 'Speaking Up: The State of the WTO Appellate Body', 22 November 2016, available at https://www.wto.org/english/news_e/news16_e/ab_22nov16_e.pdf (last visited 17 April 2018).

${ }^{7}$ WTO document WT/DSB/M/359, para. 12.1 .

${ }^{8}$ See, for example, WTO document WT/DS479/4 for DS479. The other disputes are DS480, DS482, DS 483, DS486, DS488, DS490, DS496.

${ }^{9}$ WTO document WT/DSB/M/367, Statement by Korea on delays in the dispute settlement process.

${ }^{10}$ See footnote 7 above.
} 
appeal to the date the $\mathrm{AB}$ circulates its report. ${ }^{11}$ The caseload of the Appellate Body first caught attention in 2011 when the 90-days period was exceeded in 5 out of the $7 \mathrm{AB}$ reports circulated that year. ${ }^{12}$ In communicating to the Chair of the DSB, the Chair of the $\mathrm{AB}$ explained that the workload of the Appellate Body in 2011 "reflects an overall trend of a greater number of increasingly complex appeals, with longer submissions by parties and more issues being appealed, all at a time when the resources available to the Appellate Body remain unchanged."13 The AB's caseload "remained intense" in 2012. ${ }^{14}$ Even though fewer appeals were brought that year, the $\mathrm{AB}$ predicted "intense appeal activity in the upcoming years" due to the heavy workload at the panel stage. ${ }^{15}$ In 2013 , the AB issued a paper, titled "The Workload of the Appellate Body" (Workload Paper) to the WTO membership. ${ }^{16}$ The Workload Paper identified several trends in dispute settlement activity that contribute to the "significant increase" in the AB workload: the significant growth in the average size of disputes; the increasing number of issues raised on appeal; the more frequent challenges under Article 11 of the DSU to the objectivity of a panel's factual assessments; the increasing number of participants and third participants; and the increase in the volume of submissions and the size of AB reports. ${ }^{17}$ The year 2014 witnessed "the robust level of appeal activity" predicted in the 2013 Workload Paper. ${ }^{18}$ In particular, it was marked as the "trend-setting year" in terms of complexity of appeals and the number of panel reports appealed. "Workload" remained the top concern for the AB in the years that followed. In 2015, "never before were there so many active disputes at the consultation and panel stages" and the AB's caseload was "one of the highest ever". ${ }^{20}$ The AB annual report for 2016 continued to "focus mainly on the greatly increasing workload". ${ }^{21}$ It predicted that the size, complexity and number of the upcoming appeals will "occupy a significant part of

\footnotetext{
${ }^{11}$ DSU, Article 17.5.

${ }^{12}$ WTO document WT/AB/17, Appellate Body Annual Report for 2011, 13 June 2012, p. 68. In view of the "workload of the Appellate Body", the parties in several cases jointly requested the DSB to take a decision to extend the deadline for adoption or appeal of a panel reports.

${ }^{13}$ WTO document WT/AB/17, Appellate Body Annual Report for 2011, 13 June 2012, p. 69, citing

Communication from the Chair of the Appellate Body, 5 September 2011, WT/DS399/8.

${ }^{14}$ WTO document WT/AB/18, Appellate Body Annual Report for 2012, 9 April 2013, p. 6.

${ }^{15}$ Ibid, p.7.

${ }^{16}$ WTO document JOB/AB/1, Communication from the Appellate Body, "The Workload of the Appellate Body", 23 May 2013, reproduced in Annex 1 of the Appellate Body Annual Report for 2013, 14 March 2014, WTO document WT/AB/20, 14 March 2014.

${ }^{17}$ Ibid.

${ }^{18}$ WTO document WT/AB/24, Appellate Body Annual Report for 2014, July 2015, p.6.

${ }^{19}$ Ibid.

${ }^{20}$ WTO document WT/AB/26, Appellate Body Annual Report for 2015, 3 June 2016, p.6.

${ }^{21}$ WTO document WT/AB/27, Appellate Body Annual Report for 2016, 16 May 2017, p.6.
} 
Appellate Body Secretariat staff resources for exceptional long time periods". ${ }^{22}$ In March 2018, the AB issued notices in 4 of the 7 then pending AB proceedings indefinitely postponing circulation of the $\mathrm{AB}$ report (a circulation date will be communicated to parties "after the oral hearing") because of (i) "substantially enhanced workload in 2017", (ii) "increasing overlap" in $\mathrm{AB}$ divisions "owing to the current vacancies on the Appellate Body" (at the time of writing, 3 of the 7 AB seats remain open), (iii) resulting "demands ... on the WTO Secretariat's translation services" and (iv) "the shortage of staff in the Appellate Body Secretariat". ${ }^{23}$ Two other AB proceedings still pending at the time of writing (April 2018) were filed, respectively, in October 2016 and June 2017, with no circulation date in sight. ${ }^{24}$

This paper uses count data in an attempt to better understand and unpack the various aspects of the WTO's caseload. It explores how the caseload has evolved since 1995 and examines various reasons why the system reached today's situation. We also make a forecast of what panel and AB caseload may be in the years ahead.

WTO dispute settlement does, indeed, currently experience a peak in terms of the total number of cases pending before panels and the AB. However, this is not due to an increase in new cases filed (new consultation requests markedly reduced, from a high of 50 in 1997 to "only" 17 in 2017), but rather because pending cases take much longer to conclude as they have become more complex and are often delayed for lack of human resources. In addition, fewer cases filed get formally settled (from $20 \%$ in the first five years of the WTO to almost zero after 2014), appeal rates remain very high (on average 68\%), and the share of follow-up disputes over compliance (DSU Art. 21.5) has markedly increased (from 11\% of panel caseload between 1999-2003 to 24\% between 2013-2017), all three factors leading to more (pending) caseload without actually more (new) cases filed, or more panel or AB reports issued (the number of reports produced per year has actually gone down, dropping from a peak of 26 panel reports and 13 AB reports in 2000, to "only" 13 panel reports and 6 Appellate Body reports in 2017). WTO dispute settlement is also predominantly used (i) for certain types of disputes (45\% of cases filed between 2012-2016 are trade remedy disputes,

\footnotetext{
${ }^{22}$ Ibid.

${ }^{23}$ See WTO document WT/DS486/8 of 9 March 2018, WTO document WT/DS490/7 and WT/DS496/8 of 27 November 2017, WTO document WT/DS472/10 and WT/DS497/8 9 of 14 March 2018, and WT/DS381/46 of 14 March 2018.

${ }^{24}$ See WTO document WT/DS353/29 of 20 September 2017 and WT/DS316/31 of 17 January 2018.
} 
compared to only $23 \%$ between $1995-1999 ; 48 \%$ of all AB reports involve trade remedies) and (ii) for disputes between a small subset of WTO members (20 WTO Members represent $85 \%$ of DSU participation as main party; by 2014 only $22 \%$ of WTO Members, counting the EU-28 as one, had ever been a main party before the $\mathrm{AB}^{25}$ ). Measuring "success" of the system therefore varies depending on the angle taken. ${ }^{26}$

Looking forward, we forecast that the current glut in WTO caseload will not last. More specifically, after a temporary drop in 2019, we forecast a record-breaking spike in 20202022 (with a peak of 36 concurrent panels and 11 concurrent AB proceedings), after which WTO caseload will fall back and stabilize at numbers we have seen before: under a "business as usual" scenario (using the lengthy, average timeframes since 2016), 21-22 panels and 6-7 $\mathrm{AB}$ proceedings (similar to panel/AB averages of the last five years); under more optimistic scenarios ("back to normal", using average timeframes for the first 10 years of the WTO, and "more settlements, less appeals", assuming only $46 \%$ of consultation requests move to a panel and an appeal rate of only 50\%), stabilization occurs earlier (2021) and at considerably lower levels: for panels, respectively, around 10-12 and a mere 6-7 cases; for the $\mathrm{AB}$, respectively, around 2-3 and a mere 1-2 cases. In other words, in none of these scenarios is there reason to panic today (e.g. to massively hire additional, long-term WTO Secretariat staff; temporary hires to address the 2020-2022 spike would suffice). Moreover, relatively small improvements -- panels and the AB renewing compliance with timeframes set out in the DSU; the system improving on its "clearly preferred" solution of settlement ${ }^{27}$, and parties exercising restraint when it comes to appealing panel reports -- would bring WTO caseload down to surprisingly low levels. But there is also a "worst case scenario": if WTO Members continue to fail to fill vacancies on the Appellate Body, WTO dispute settlement will grind to a halt in December 2019, at which time only 1 individual would remain on the $\mathrm{AB}$, making it impossible for the $\mathrm{AB}$ to function (an $\mathrm{AB}$ division hearing an appeal must be composed of 3 members). As of that date, any WTO Member could then block the adoption of an adverse panel report by simply appealing the report.

\footnotetext{
${ }^{25}$ Joost Pauwelyn, 'Minority Rules: Precedent and Participation before the WTO Appellate Body', in Joanna Jemielniak, Laura Nielsen and Henrik Palmer Olsen (Eds.), Establishing Judicial Authority in International Economic Law (Cambridge: Cambridge University Press, 2016), 139 ff.

${ }^{26}$ See M. Elsig, B. Hoekman, \& J. Pauwelyn, 'Thinking about the performance of the World Trade Organization: a discussion across disciplines', in M. Elsig, B. Hoekman, \& J. Pauwelyn (Eds.), Assessing the World Trade Organization: Fit for Purpose? (Cambridge: Cambridge University Press, 2017)

${ }^{27}$ See DSU Article 3.7 : «A solution mutually acceptable to the parties to a dispute ... is clearly to be preferred".
} 


\section{The "Tsunami" of Cases Pending before WTO Panels and the AB}

We start by assessing the "pending caseload" at the panel and the AB stage by calculating the total number of active panels and appeals at any given month from January 1995 to March 2018. To accurately capture pending caseload disputes on the same matter filed by multiple complainants but heard by the same panel or the same AB division are counted only once. We also take into consideration compliance panels composed under DSU Article 21.5 and appeals, if any, associated with these compliance panel reports. With "active" we mean a dispute pending before a panel established by the DSB and for which panelists have been appointed, or an appeal that has been referred to the $\mathrm{AB}$. Once the panel or AB circulates its report, we take the dispute off the "pending caseload" list. Notice that "active" thus defined does not necessarily mean that the dispute is being actively considered or examined, or that WTO adjudicators or staff are actively working on it (this is also why we prefer the notion of "caseload" over that of "workload"). As further discussed in Section 9 below, a panel or AB division may be appointed but delay the actual start of its work (e.g. receiving submissions, holding hearings) for lack of WTO Secretariat staff or available AB members, especially in recent years. In this sense, the actual "workload" of people involved in WTO dispute settlement may be well below the "pending caseload" we detect: many cases have been "pending" for much longer not because they took more time to examine per se, but because they have been (passively) waiting in the queue until available human resources freed up. In recent $A B$ proceedings, for example, the $\mathrm{AB}$ immediately appointed three $\mathrm{AB}$ members to consider the appeal and right away accepted party briefs, but then postponed the hearing with the parties for months (mainly for lack of human resources), after which the $\mathrm{AB}$ report was then relatively promptly issued. In this case, the delay was due not because of longer examination or deliberation over the case, but rather time "lost" between the submission of briefs and the oral hearing. ${ }^{28}$

Figure 1 presents the evolution of the WTO pending caseload at the panel stage from 1995 to April 2018. As mentioned in the introduction, the caseload at the panel stage caught attention in 2015. In fact, our data shows that the surge in pending caseload is nothing new to the system. For example, in March 1999, the number of concurrent panels (including

\footnotetext{
${ }^{28}$ In Indonesia - Import Licensing Regimes, for example, the AB proceeding took 265 days (WT/DS477/AB/R, 9 November 2017). Yet, all briefs were filed within 22 days. Thereafter more than 5 months passed before the $\mathrm{AB}$ hearing was held. After the hearing the $\mathrm{AB}$ report was issued within 72 days.
} 
Art. 21.5 panels) reached 18 (the same as today, 30 April 2018). From October 1999 to May 2000, for eight months in a row the pending caseload was above 15 and reached 19 at the peak. Similarly, from January to July 2007, for seven months in a row the pending caseload was above 15 . However, these caseload surges all subsided shortly afterwards. The most recent surge in caseload started to build up since 2013. From January 2014 to April 2018, for more than 52 months in a row there were 17 to 26 concurrent panel proceedings. Never before has this persistent level of high caseload been seen in WTO dispute settlement. The absolute record to date was set in August 2016: a total of 26 panels were then pending. At the cut-off date for this paper (30 April 2018), the total had reduced to 18 .

\section{Figure 1: Pending WTO panels by month}

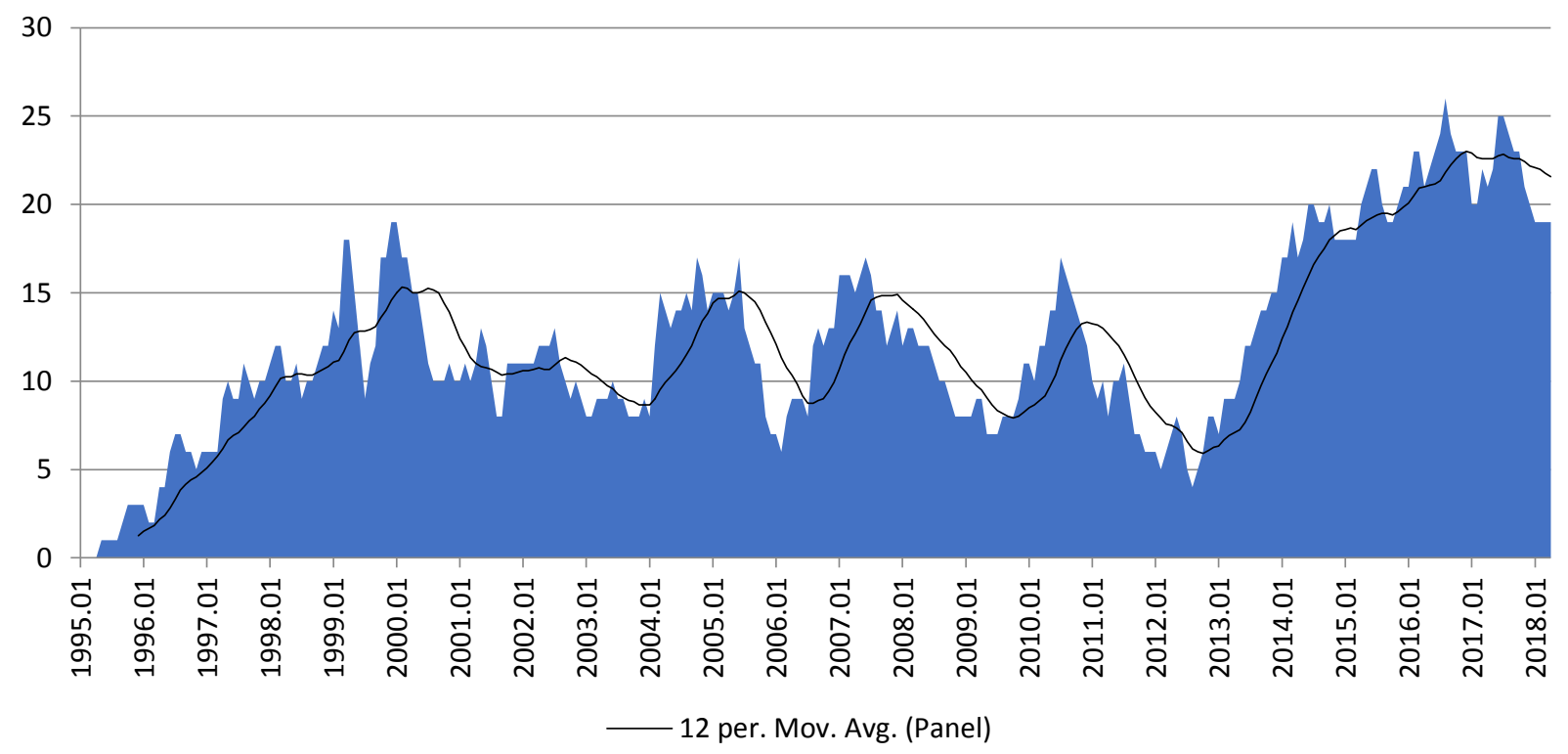

The AB's caseload is presented in Figure 2. The pattern shown below is a bit different from that of the panel stage, as the ups and downs are more frequent. This is related to the AB's specific features. To recall, the $\mathrm{AB}$ consists of 7 part-time members with 3 members serving on each appeal. As mentioned before, the AB's caseload first caught attention in 2011. Indeed, for two thirds of the months in 2011 the AB had to deal with 4 or 5 appeals at the same time. This caseload was relatively high, but not unusual for the AB. For example, between 1999 and 2001, for 19 out of 36 months there were at least 4 concurrent appeals. At times, the caseload even reached 6 (December 2000 and October 2001). Indeed, the AB's Workload Paper referred to reasons other than the mere number of 
pending appeals that had contributed to their workload. The recent surge in caseload, starting to build up in 2014, is more persisting and unprecedented. From February 2017 to April 2018, for 15 months in a row there were at least 5 concurrent appeals. More significantly, from August 2017 to April 2018, the appeals that the AB was concurrently dealing with remained at minimum 7. In September 2017 it reached an all-time high of 9. At the cut-off date for this paper, 30 April 2018, it had fallen back to 8. Thus, the predicted "tsunami" in the AB's caseload in 2017 is real.

\section{Figure 2: Pending AB proceedings by month}

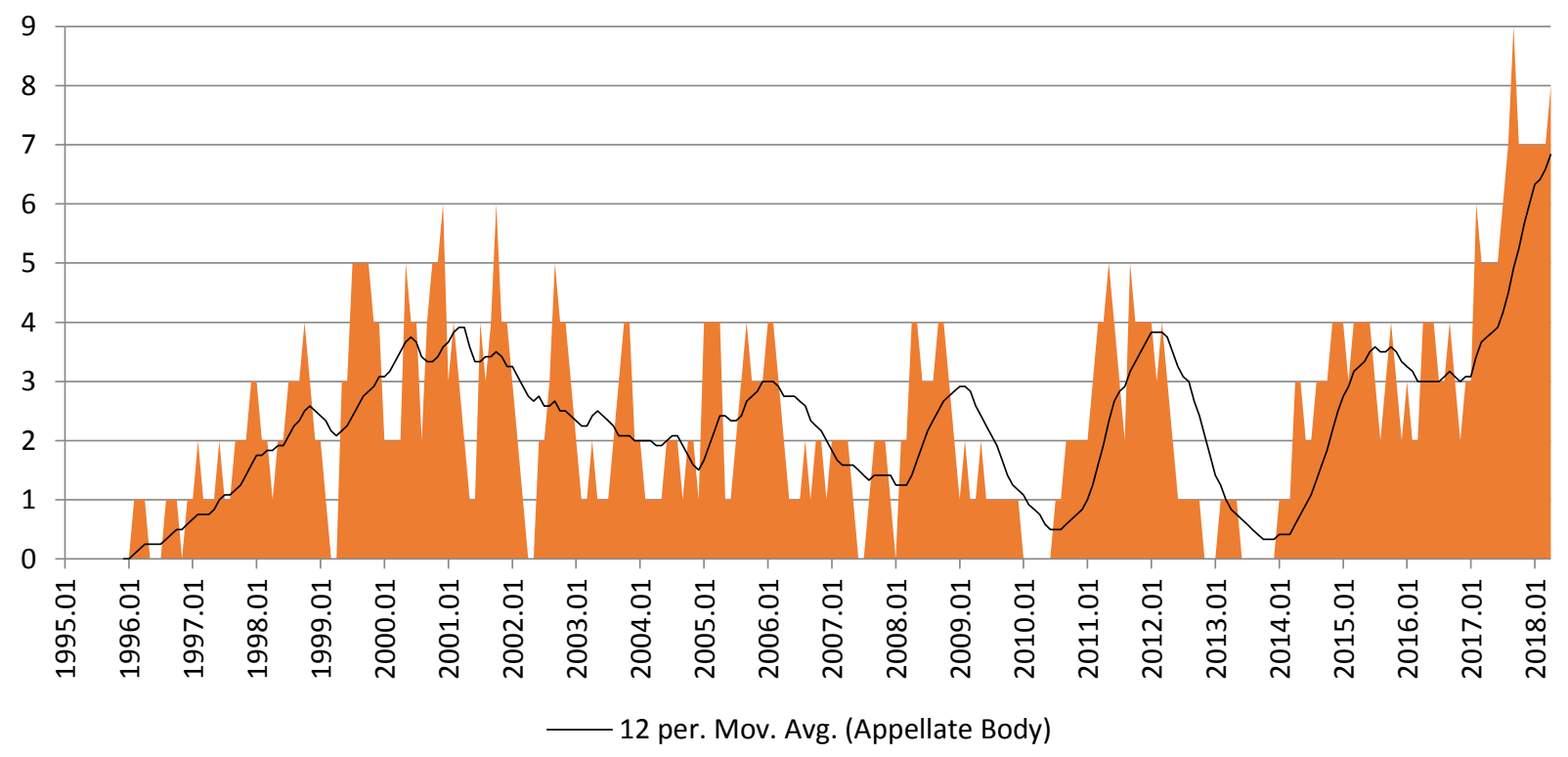

\section{WTO Secretariat Legal Staff Has More Than Doubled}

As mentioned earlier, these unprecedented panel and $\mathrm{AB}$ caseloads are largely due to longer proceedings (see also Figures 11-1 and 11-2 below) and delays which, in turn, are often explained, at least partly, by lack of, in particular, WTO Secretariat staff (further discussed in Section 9 below). In response to these challenges, the WTO Secretariat recruited more legal support staff to assist panels and the $A B$, especially after 2015 . The following chart illustrates the number of staff in the three legal divisions of the WTO Secretariat, namely the Legal Affairs Division, the Rules Division and the AB Secretariat. Altogether, as Figure 3-2 shows, the number of staff in these three divisions has more than doubled compared with that of the beginning of the century, from 37 in 2000 to 83 in 2017. 
Figure 3-1: Number of staff in Legal Affairs Division, Rules Division and Appellate Body Secretariat ${ }^{29}$

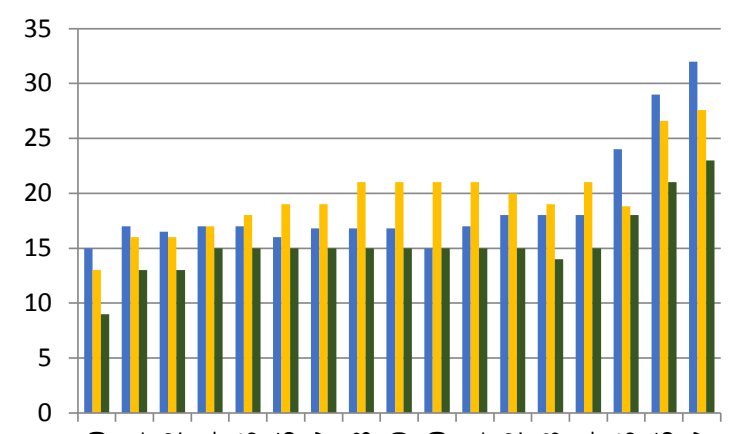

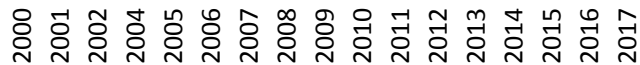

Figure 3-2: Total number of staff in Legal Affairs Division, Rules Division and Appellate Body Secretariat

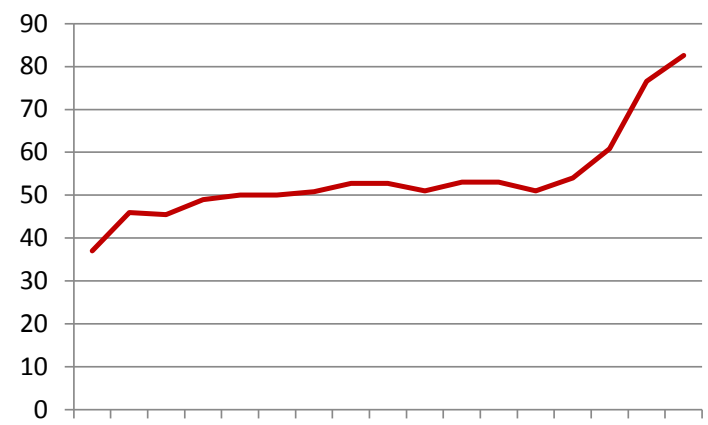

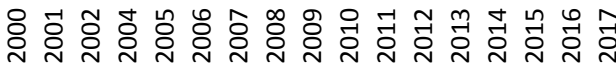

- Legal Affairs Rules Appellate Body

In short, the "tsunami" in WTO caseload, at least in terms of pending panel and AB proceedings running concurrently, is real. Whether WTO adjudicators and the WTO Secretariat managing and assisting panels and the AB are "busier than ever" is another question: especially since 2015, many cases have been "pending" for much longer not because they took more time to examine per se, but because they have been (passively) waiting in the queue until available human resources freed up. WTO disputes have become more complex, thereby taking longer to examine. However, also WTO legal staff has increased over time, more than doubling since 2000.

\section{The Decline in New WTO Disputes Filed}

What are the reasons that have contributed to the "tsunami" in pending cases before panels and the AB? Every WTO dispute starts with a request for consultations. We start our analysis from the number of consultations or new disputes filed per year. As Figure 4 shows, and in contrast to what one might expect from the caseload described in Section 2, the number of new disputes filed has actually decreased, not increased, since the creation of the WTO. In the first five years, WTO Members filed, on average, 37 consultation requests per year. This number dropped to less than half -16 requests per year on average for the last five years up to 2017. Thus, we are facing a puzzle. On the one hand, panel, AB and WTO Secretariat caseload, expressed in terms of pending cases at any given time, did,

\footnotetext{
${ }^{29}$ See WTO Annual Report for each of the years from 2000 to 2017, available at: https://www.wto.org/english/res_e/reser_e/annual_report_e.htm. However, the 2003 Report does not contain information on the number of staff in each Division.
} 
indeed, increase and the system is struggling to address the challenge. On the other hand, we see a reduction in the number of new disputes brought to the WTO.

Figure 4: New WTO dispute settlement cases filed per year ${ }^{30}$

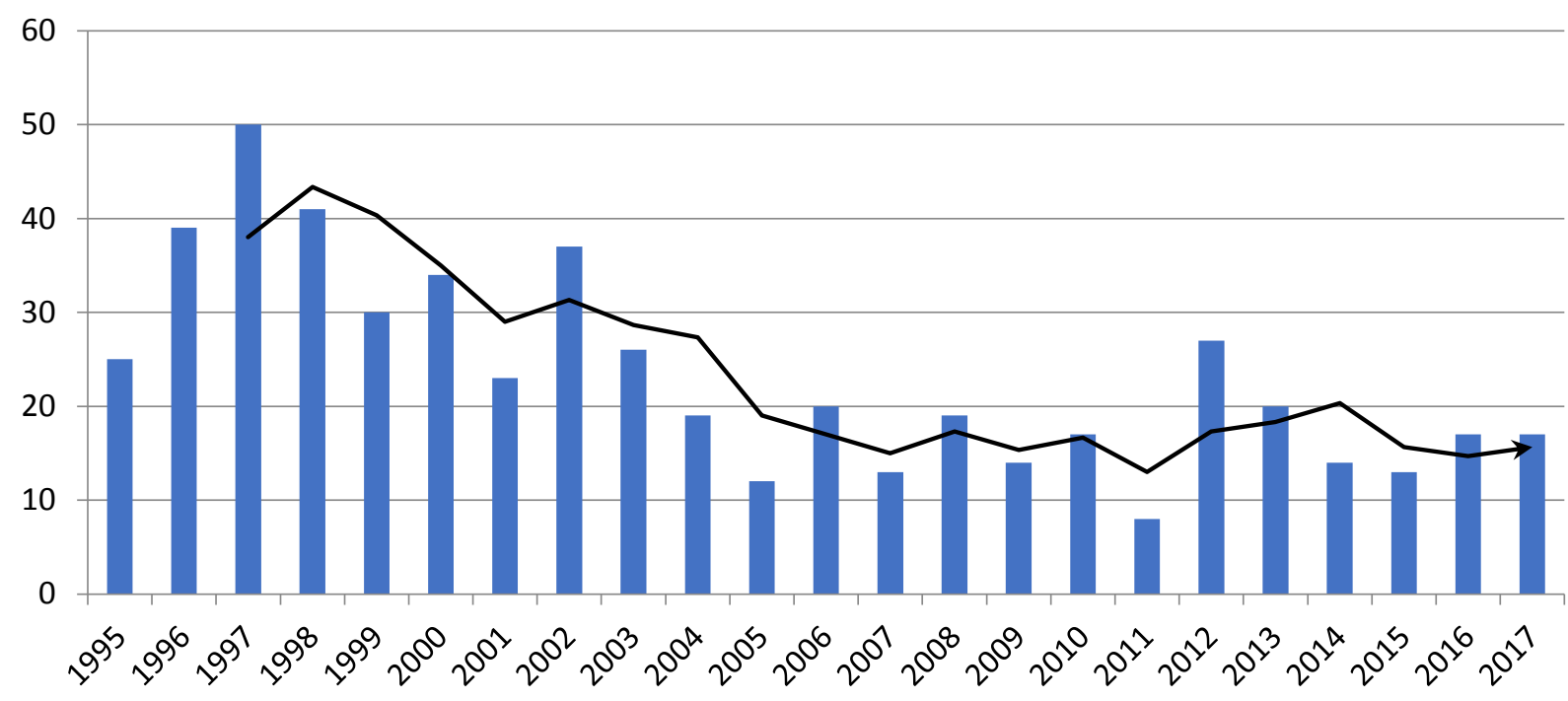

\section{Fewer New Cases, But A Larger Share Moves On To The Panel Stage}

Our data shows that, even though the number of new WTO disputes filed declined over the years, the relative share of disputes going to the panel stage has increased. In the first five years since the WTO's establishment, only 85 of 185 disputes moved to the panel stage. That is $46 \%$ of total consultation requests filed from 1995 to 1999 . In the last five years from 2012 to $2016,75 \%$ (68 of 91) of the consultations filed subsequently led to a panel request. $^{31}$ In other words, once a consultation request is filed, it is increasingly unlikely that the parties will settle or abandon the case without going to a panel. As a result, the declining number of new disputes filed did not result in a proportional decline of disputes at the panel stage: fewer disputes may be filed, but more of them advance to the panel stage.

\footnotetext{
${ }^{30}$ Trendlines are based on 3-year moving average.

${ }^{31}$ As WTO consultations take time, at least a few months, for disputes initiated in 2017 , it is yet too early to predict the result for these consultations. Thus, for this Section, the data analyzed reflects the result for cases initiated up to the end of 2016.
} 
Figure 5: Share of WTO disputes moving to the panel stage

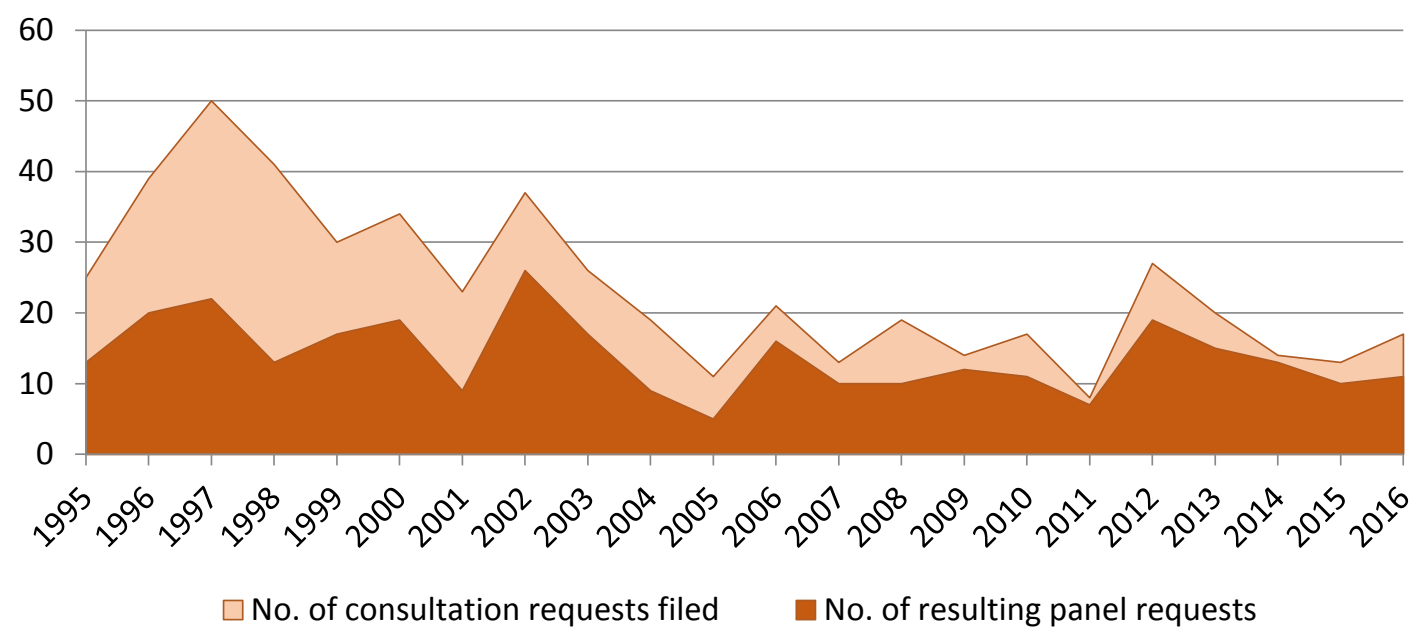

The increase in the proportion of cases moving to the panel stage can, at least, be partially explained by the fall in settlements reached before the panel stage. Under our data, a dispute is "formally settled" if the request is withdrawn, the measure giving rise to the dispute is terminated, or a mutually agreed solution is notified to the DSB. As Table 1 shows, the proportion of disputes formally settled before a panel request was filed dropped significantly from $20 \%$ in the first five years of the WTO to almost zero after 2014. The same trend is also true for disputes settled during the panel proceedings but before the circulation of the panel report. ${ }^{32}$ Altogether, in the first 15 years of the WTO, a considerable percentage (22.16\%) of disputes filed were formally settled before the circulation of a panel report. Most of them $-20 \%$ of all the disputes -- were settled even without going to a panel. However, since 2010 only 2 disputes for which a panel was established were formally settled before circulation of a panel report. This indicates that over time the formal settlement rate in WTO dispute settlement reduced significantly: Once WTO Members formally submit a dispute to WTO dispute settlement, the chances of a formal settlement are nowadays very low. This raises the question of whether the consultation stage has, in practice, become a pure formality and lost its settlement function. Notice that not all disputes that are not formally settled lead to a panel report; a substantial part of WTO disputes just linger, without a formal settlement nor moving on to the panel stage (35\% for those filed between 1995-2015).

\footnotetext{
${ }^{32}$ See Table 1, column "Settled during the panel proceedings".
} 
Table 1: Share of disputes "formally settled" before the circulation of a panel report

\begin{tabular}{|l|c|c|c|}
\hline & $\begin{array}{l}\text { Settled during the } \\
\text { consultations (\%) }\end{array}$ & $\begin{array}{l}\text { Settled during the } \\
\text { panel proceedings }(\%)\end{array}$ & $\begin{array}{l}\text { Total } \\
(\%)\end{array}$ \\
\hline $1995-1999$ & 20 & 2.7 & 23 \\
\hline $2000-2004$ & 12 & 6.5 & 18 \\
\hline $2005-2009$ & 12 & 6.4 & 19 \\
\hline $2010-2014$ & 1.2 & 1.2 & 2.3 \\
\hline $2015-2016$ & 0 & 0 & 0 \\
\hline
\end{tabular}

Figure 6: Share of disputes filed in a given year that were "formally settled" before the circulation of a panel report

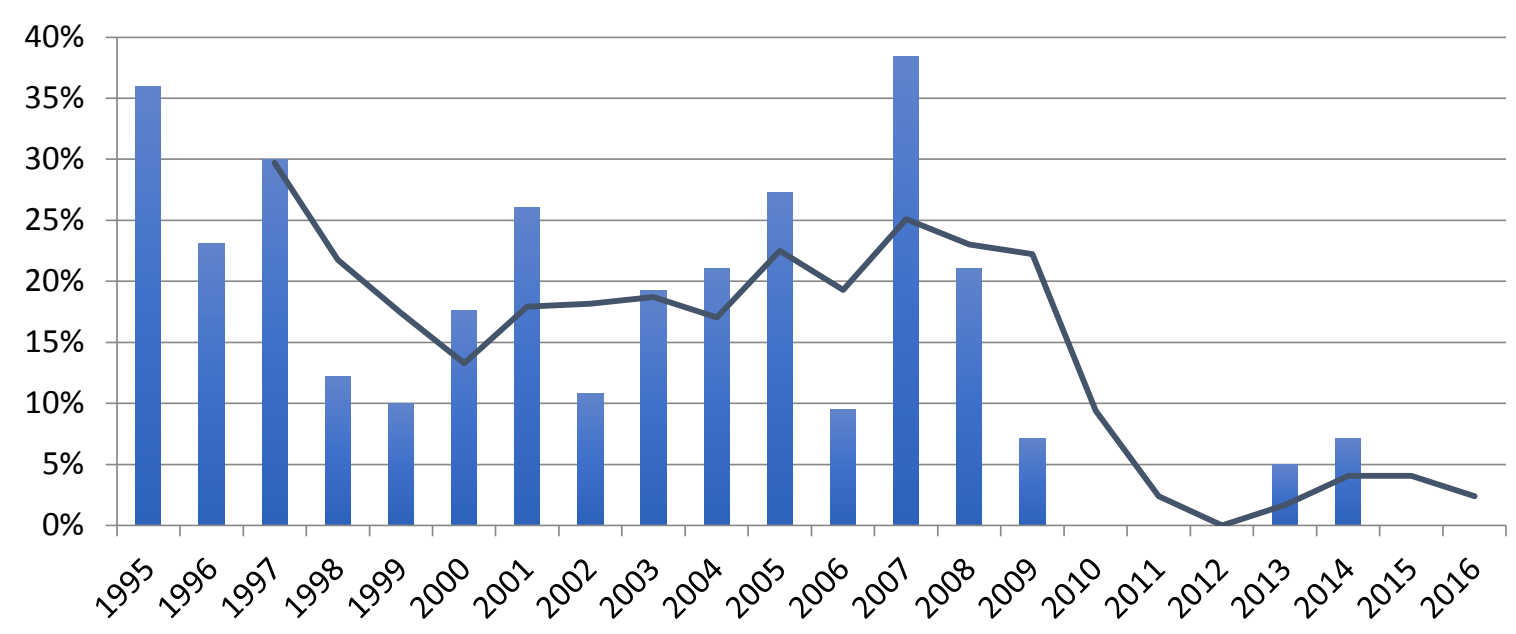

\section{More Trade Remedy Disputes, Less Settlements}

The declining number of new disputes brought to the WTO (Section 4) combined with a mounting reluctance to settle cases formally filed (Section 5) leaves the number of cases moving to a panel relatively stable. This partly explains the "tsunami" of pending cases (Section 2) notwithstanding the reduction in new cases filed. We now turn to the changing nature of the disputes brought to the WTO as it may partly explain the reduced settlement rate.

According to the DSU, a WTO Member may bring a case concerning measures affecting the operation of any covered agreement. ${ }^{33}$ The covered agreements refer to the Marrakesh Agreement Establishing the WTO, the multilateral agreements on trade in goods, the

\footnotetext{
${ }^{33}$ DSU, Article 4.2.
} 
GATS, the TRIPS, the DSU, and two plurilateral trade agreements. ${ }^{34}$ Figure 7 explores the likelihood of settlement for a case involving a particular covered agreement. As highlighted in red, only $4.4 \%$ of the cases involving a subsidy claim were settled before the circulation of a panel report; $6.4 \%$ for safeguard cases and $6.9 \%$ for cases concerning antidumping measures (compared to the overall settlement rate of $16.2 \%$ ). Disputes involving these three agreements are often labeled as trade remedy disputes. In other words, compared with cases concerning other covered agreements, trade remedy disputes are less likely to get settled. Indeed, trade remedy disputes have distinct features compared with other disputes. They are highly technical and specifically applying to one or more companies or countries. Moreover, under, for example, US trade remedy laws, the US executive does not normally have the power to withdraw or change an anti-dumping or countervailing duty without a prior adverse WTO or NAFTA ruling. This makes it technically impossible for many trade remedy disputes to "formally settle".

Figure 7: Share of settled disputes for each covered agreement

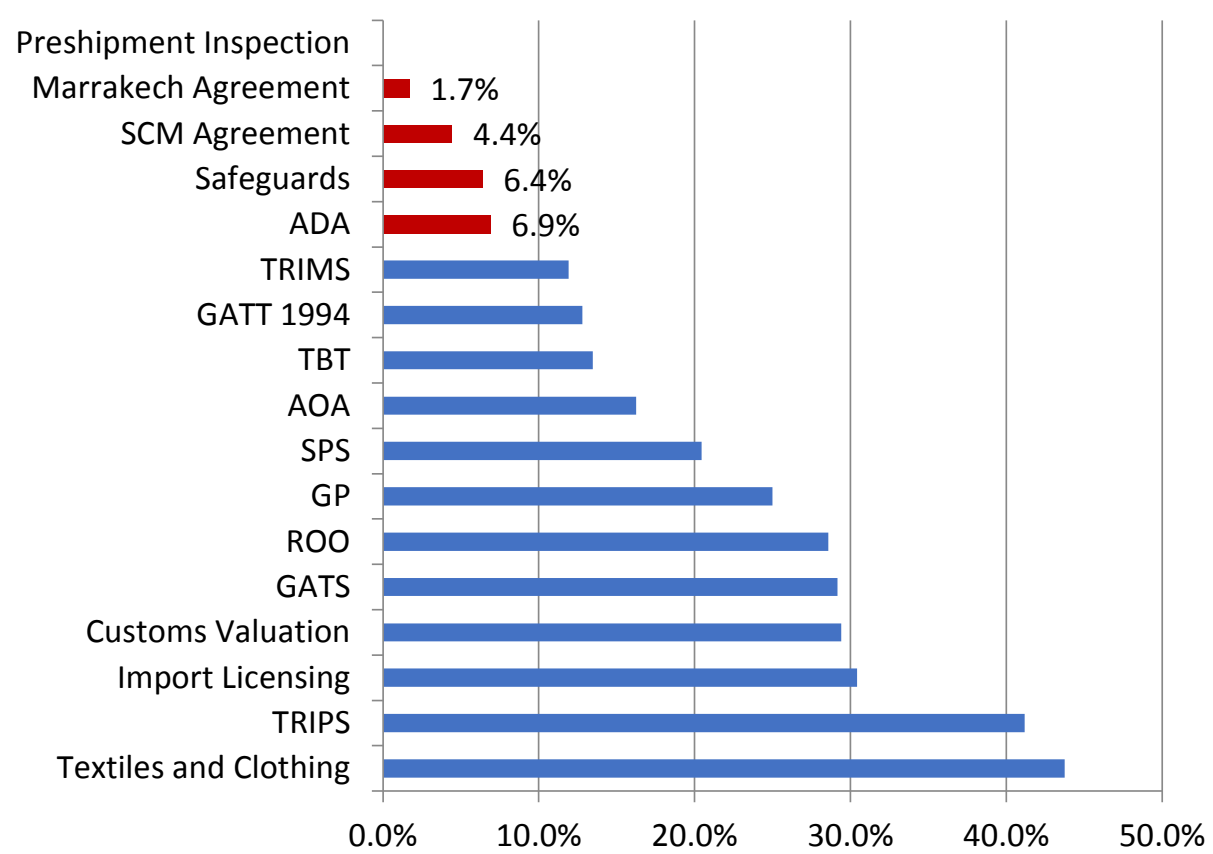

To recall, we just observed that in the past ten years it has been increasingly difficult to witness settlement before a panel report is circulated. In light of the above finding that trade remedy disputes tend to be more difficult to settle than other disputes, one could reasonably expect that the relative number of trade remedy disputes has increased over

\footnotetext{
${ }^{34}$ DSU, Article 1 and Appendix 1.
} 
time. Figures 8-1 and 8-2 compare the share of trade remedy disputes in the first 5 years of the WTO to that for the most recent five years to test this hypothesis. While trade remedy disputes only represented 23\% of the total disputes brought to the WTO from 1995 to 1999 , that share almost doubled to $45 \%$ in the past five years. On average it now stands at $38 \%$. More significantly, from 2010 to 2016, a period in which very few settlements were observed, trade remedy cases accounted for $48 \%$ of the total number of new WTO disputes filed. $^{35}$

Figure 8-1: Share of trade remedy disputes filed 1995-1999

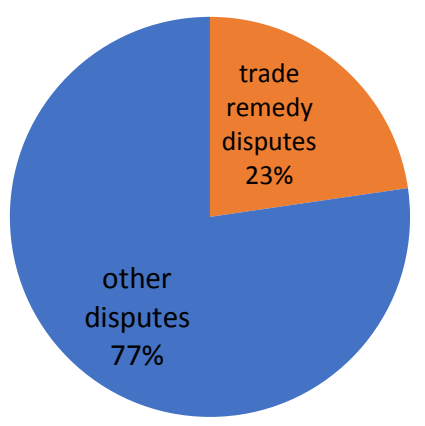

Figure 8-2:

Share of trade remedy disputes 2012-2016

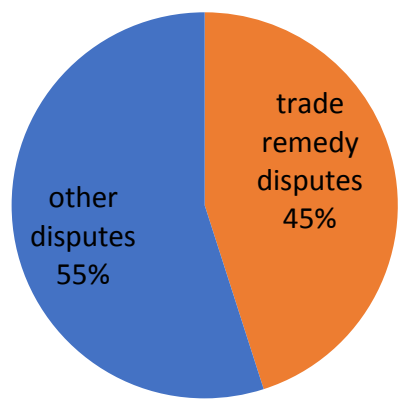

\section{Less New Disputes Filed, But Relatively More Compliance Disputes in Old}

\section{Cases}

When the parties to a dispute do not agree on whether the responding member has implemented the recommendations in the adopted panel or $\mathrm{AB}$ report, either of them can request a so-called compliance panel under Article 21.5 of the DSU. The concerning Members can bring such request at any time following the end of the implementation period. Sometimes, a party may take years to initiate a DSU Article 21.5 dispute. For example, in Chile - Agricultural Products, while the AB report was issued in September 2002, it was not until three years later that a compliance panel was requested. In a few cases, parties struggled with implementation even after a first compliance panel report and $\mathrm{AB}$ report was adopted, and resorted to Article 21.5 DSU for a second time. ${ }^{36}$

\footnotetext{
${ }^{35}$ The relationship between whether a case is a trade remedy case and whether the case is likely to settle can further be tested statistically by a so-called Chi-Squared test. The resulting P-value for the chi-square test is 0.0000007 . This is a number much smaller than the threshold of 0.05 . Thus, whether the case is a trade remedy case or not is highly relevant to the chance of settlement.

${ }^{36}$ These cases include: EC - Bananas (DS27), Brazil-Aircraft (DS46), Canada-Milk/Diary (DS103, 113), US - FSC (DS108), US - Tuna II (DS381).
} 
The first wave of panels established under DSU Article 21.5 started in 1999, when 5 such panels were composed. ${ }^{37}$ The absolute number of compliance panels composed by year did not markedly increase over time. ${ }^{38}$ Nevertheless, as there are fewer new disputes filed and the number of original panels established was kept relatively stable, panels composed under DSU Article 21.5 have become a significant contributor to the caseload at the panel stage, as illustrated in Figure 9. For example, in May 2017 there were 7 concurrent DSU Article 21.5 panels, accounting for one third of the total 21 ongoing panels at that time. On average, for the first five years from 1999 when the first DSU Article 21.5 panel was composed (1999-2003), compliance panels contributed $11 \%$ of the overall caseload at the panel stage; for the last five years from 2013 to 2017, the contribution of DSU Article 21.5 panels increased to $24 \%$. From this perspective, the relative share of active DSU Article 21.5 panels has more than doubled.

Figure 9: Active DSU Article 21.5 panels by month

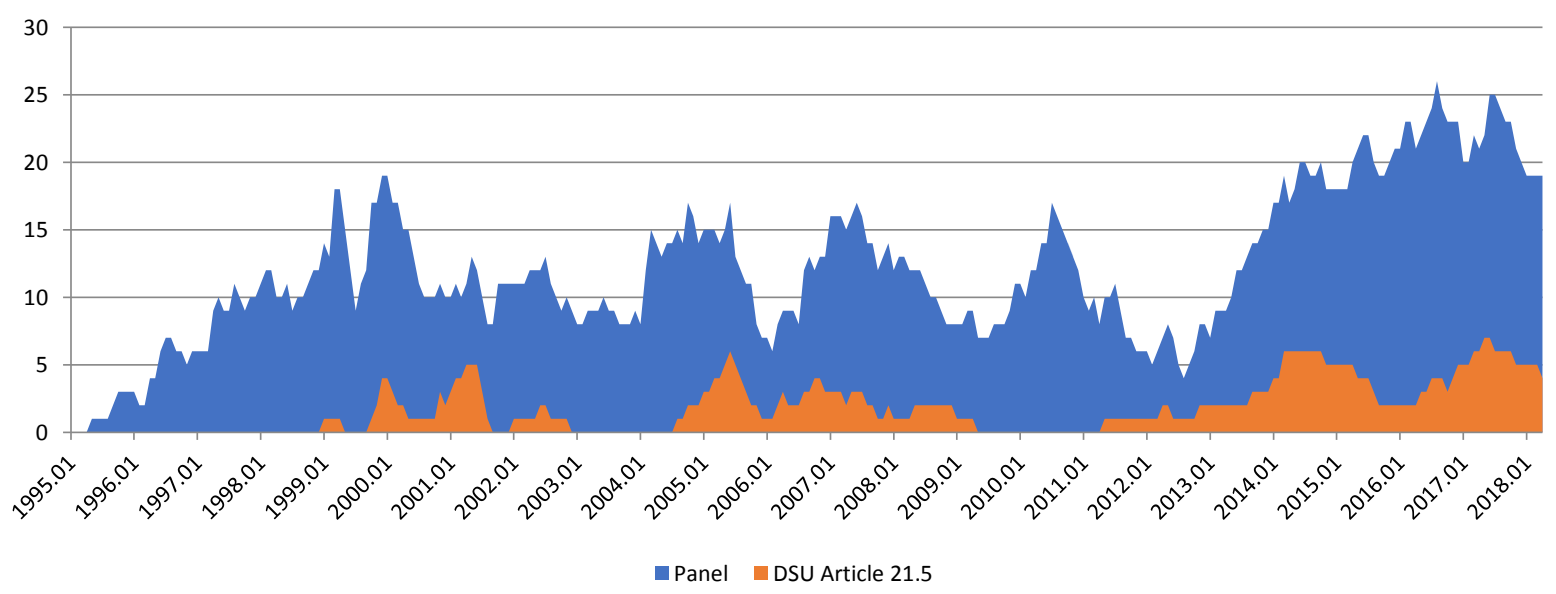

\section{No Reduction in the Rate of Appeal, No Respite for the AB Caseload}

The AB's caseload is closely related to the development of the caseload at the panel stage. For the first two years, every panel report was appealed. The average appeal rate was $88 \%$ for the first three years. It came down to $65 \%$ for the next three years between 1999 and 2001 and largely stayed at that level or went below that until it picked up again to nearly $80 \%$ between 2014 and 2016. In 2017, probably in the wake of the impasse in the selection

\footnotetext{
${ }^{37}$ They are Australia - Salmon (DS18), EC - Bananas (DS27), Brazil - Aircraft (DS46), JapanAgricultural Products (DS76), Australia - Leather (DS126).

${ }^{38}$ For the first five years from 1999 to 2003, 11 DSU Article 21.5 panels were composed. For the last five years from 2013 to 2017,10 such compliance panels were composed. Furthermore, in no other year has the number of DSU Article 21.5 panels composed exceeded that of 1999.
} 
process of new AB Members, the appeal rate dropped to 50\% (the same rate as that between 2011-2013). ${ }^{39}$ Overall, however, the appeal rate has not trended downwards (even though one could expect that as WTO rules get clarified, fewer appeals may be filed) and now stands at an average of $68 \%$. In other words, whereas the number of new disputes filed has gone down, once a dispute is filed it more likely moves on to a panel and once a panel decides, the likelihood of appeal has remained relatively stable. Thus, the heavy caseload at the panel stage is (for close to $70 \%$ ) passed on to the appeal stage.

Figure 10: Appeal rate 40

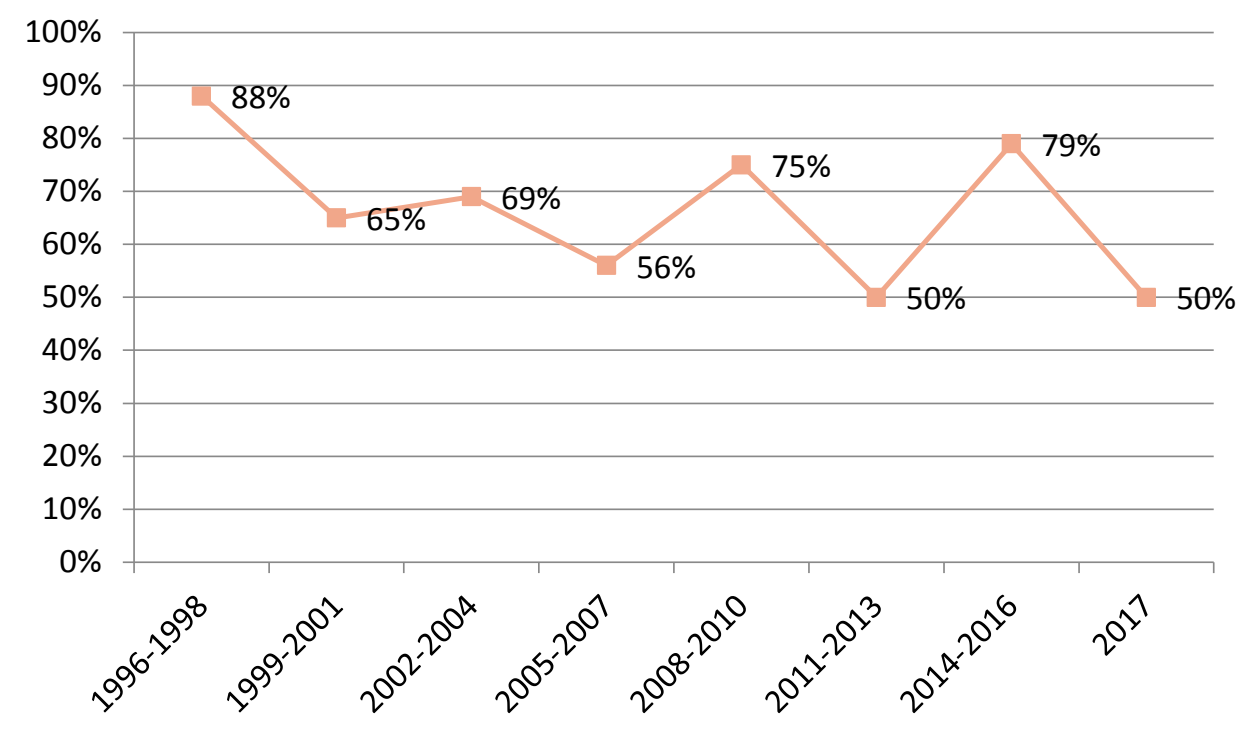

Our data further illustrates the likelihood of appeal when the dispute relates to a particular covered agreement. At the top of the list are Protocols of Accession, the Import Licensing Agreement, the Agreement on Technical Barriers to Trade (TBT Agreement), the Agreement on Agriculture (AOA), and the Agreement on the Application of Sanitary and Phytosanitary Measures (SPS Agreement). Appeal rates may be higher under those agreements as they tend to involve either newly created legal instruments, such as Protocols of Accession (100\% appeal rate), or issues that are sensitive to the government's authority

\footnotetext{
${ }^{39}$ Since August 2017, the US started blocking the selection processes for new AB members. According to the US, moving forward with filling vacancies risks perpetuating and leaving unaddressed a number of longstanding concerns that it frequently expressed. See Statements by the United States at the Meeting of the WTO Dispute Settlement Body (Geneva, 31 August 2017), available at: https://geneva.usmission.gov/wpcontent/uploads/2017/08/Aug31.DSB .Stmt .as-delivered.fin_public.pdf (last visited 11 April 2018). The US position has not changed till the last DSB meeting. See the summary of the DSB meeting on 27 April 2018, available at: https://www.wto.org/english/news e/news18 e/dsb_27apr18 e.htm (last visited 30 April 2018).

${ }^{40}$ This chart was made based on statistics from WorldTradeLaw.net, available at: http://www.worldtradelaw.net/databases/appealcount.php (last visited 30 April 2018)
} 
to regulate, such as the SPS Agreement (80\% appeal rate). At the bottom of the list are disputes under the Government Procurement Agreement (GPA) and the Trade-Related Aspects of Intellectual Property Rights (TRIPS) (with, respectively, a 0\% and a 30\% appeal rate). Although TRIPS disputes also involve a novel legal instrument and potentially sensitive questions of regulatory power, parties may, for example, be reluctant to appeal TRIPS panels so as to avoid more firmly established $\mathrm{AB}$ jurisprudence on the question. ${ }^{41}$

Table 2: Likelihood of appeal depending on the agreement in dispute

\begin{tabular}{|l|c|}
\hline Covered agreement & $\begin{array}{l}\text { Likelihood of } \\
\text { appeal }(\%)\end{array}$ \\
\hline GPA & 0.0 \\
\hline TRIPS & 30 \\
\hline Customs Valuation & 50 \\
\hline ADA & 54 \\
\hline Trade remedy disputes & 60 \\
\hline SCM & 65. \\
\hline GATS & 71 \\
\hline GATT 1994 & 72 \\
\hline Marrakech & 73 \\
\hline TRIMS & 74 \\
\hline ROO & 75 \\
\hline Safeguards & 75 \\
\hline SPS & 80 \\
\hline AOA & 85 \\
\hline TBT & 87 \\
\hline Import Licensing & 89 \\
\hline Protocol of Accession & 100 \\
\hline
\end{tabular}

Note that even though the likelihood of trade remedy disputes being appealed is somewhat lower compared to the average appeal rate $(60 \% \mathrm{v} .68 \%)$, the share of trade remedy disputes in all the circulated $\mathrm{AB}$ reports remains high (on average 48.5\%).

\section{Fewer New Cases, But Cases Filed Are More Complex and Take Longer}

We also observe that, over time, it has taken longer to complete panel and $\mathrm{AB}$ proceedings. This offers a further explanation for why the number of pending cases at any given time has increased (Section 2) even though the number of new cases filed has actually decreased

\footnotetext{
${ }^{41}$ See Joost Pauwelyn, The Dog That Barked But Didn't Bite: Fifteen Years of Intellectual Property Disputes at the WTO, 1 Journal of International Dispute Resolution (2010), 389-429.
} 
(Section 4): Cases just take longer to wind their way through the process, with no retroactive remedies as a backstop, as WTO remedies are prospective only, more specifically, an obligation to bring the measure into compliance after a reasonable period of time following the circulation of the adverse panel or $\mathrm{AB}$ ruling (damage for past harm or harm caused during panel or AB proceedings is not compensated). ${ }^{42}$ Longer proceedings, in turn, may partly explain the reduced rate of filing new disputes: potential claimants may be discouraged from filing a new case given the length of time it takes to get a final decision. Figure 11-1 shows the average number of days taken between a panel's composition and when the final panel report is circulated for all cases where a panel report was circulated in a given year. For panel reports circulated in 1996, it only took a panel on average 230 days. For panel reports circulated in 2017, in contrast, it took on average 710 days, a more than threefold increase. The longest proceeding ever took 1717 days and the shortest 126 days. Figure 11-2 illustrates the average time taken between a notice of appeal and the circulation of the $A B$ report in any given year that $A B$ reports were circulated. $A n$ upward trend can also be observed there: For AB reports circulated in 1996, it took on average 60 days to complete an appeal proceeding, while in 2017 it took on average 223 days. The latest $\mathrm{AB}$ report circulated at the time of writing (a report circulated in March 2018), took a record-breaking 395 days. ${ }^{43}$ Yet, another AB proceeding still pending has already broken this record: as of April 30, 2018, one of the Airbus/Boeing (Art. 21.5) appeals has been pending for an unprecedented 564 days and counting. ${ }^{44}$

\footnotetext{
${ }^{42}$ DSU, Articles 19.1, 21 and 22.

${ }^{43}$ DS479.

${ }^{44}$ DS316.
} 
Figure 11-1: Average time for a Panel proceeding $^{45}$

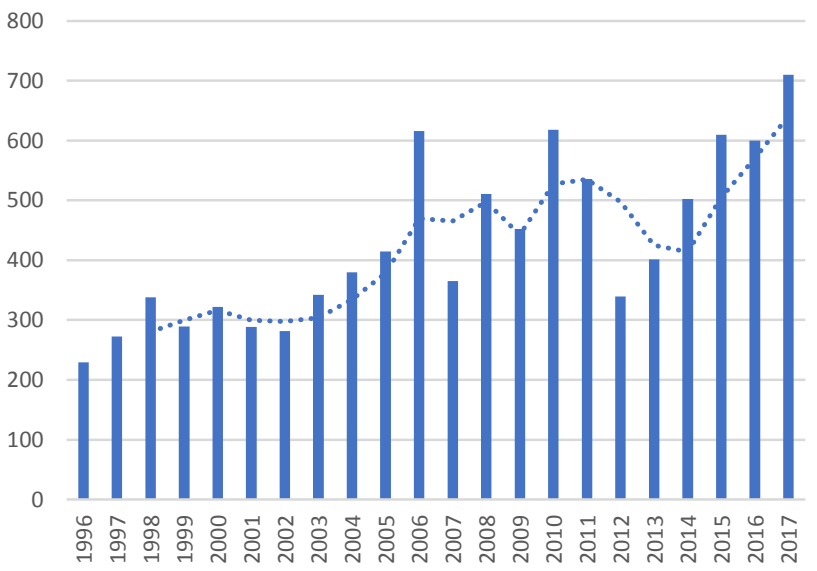

Figure 11-2: Average time for an Appellate Body proceeding ${ }^{46}$

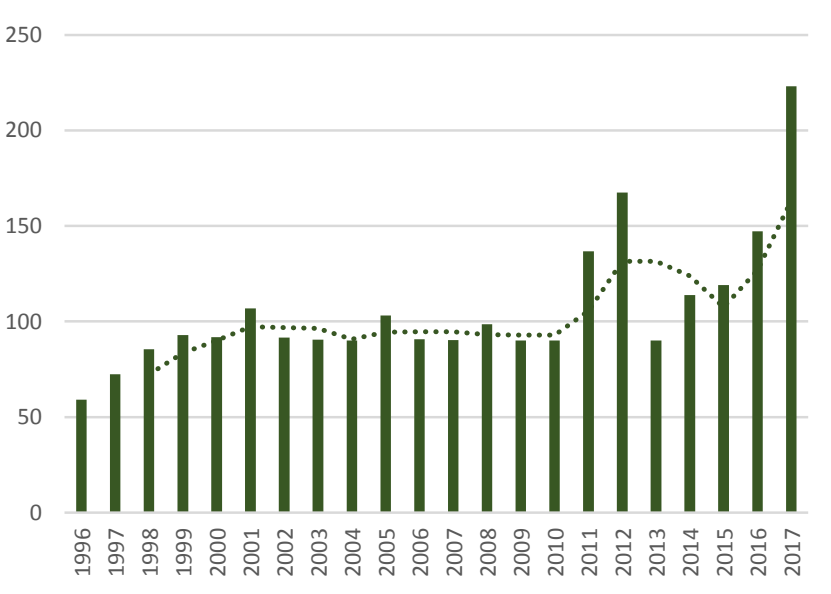

The longer duration of cases can be explained, firstly, by the increasing complexity of WTO disputes. Whereas disputes filed between 1995 and 2000 had on average 8 distinct claims listed in their consultation requests, disputes filed between 2009 and 2013 contained on average 23 claims. ${ }^{47}$ The WTO also observed that there are three times as many exhibits per panel now than in early WTO days. ${ }^{48}$ Other possible reasons for longer panel proceedings are delays in the effective start of a panel's work for lack of WTO staff ${ }^{49}$ (further discussed below), and the parties' strategic choice to suspend the panel work. In EU-Biodiesel (Indonesia), for example, the Panel suspended the proceedings at the request of the complaining party for 186 days. ${ }^{50}$ The $\mathrm{AB}$, in turn, reported that it witnessed a considerable increase in (i) the number of issues appealed per case, (ii) the number of parties and third participants involved in a given case, and (iii) the length of submissions and exhibits it receives per case. ${ }^{51}$ Over time, also more WTO jurisprudence is created, arguably adding to the detail and complexity of both party arguments and the analysis by panels and the AB.

\footnotetext{
45 The trendline is based on a 3-year moving average.

${ }^{46}$ The trendline is based on a 3-year moving average.

47 These numbers are calculated based on "The WTO Dispute Settlement Data Set 1995-2016" made publicly available by Louise Johannesson and Petros C. Mavroidis, available at

http://cadmus.eui.eu/handle/1814/44568 (last visited 20 June 2017). See also WTO Room Document, Current Dispute Settlement Activity, Annex to Director-General's Statement at the DSB Meeting of 28 October 2015, available at: https://www.wto.org/english/news_e/news15_e/dsbannex_e.pdf (last visited 08 May 2018).

${ }^{48}$ WTO Room Document, Current Dispute Settlement Activity, Annex to Director-General's Statement at the DSB Meeting of 28 October 2015, available at: https://www.wto.org/english/news_e/news15_e/dsbannex_e.pdf (last visited 08 May 2018).

${ }^{49}$ See footnote 8 above.

${ }^{50}$ For example, in DS480, the panel proceeding was suspended at the Complainant's request. See WTO document WT/DS480/5, Communication from the panel, 12 July 2017.

${ }^{51}$ See footnotes 13 and 16 above.
} 
In Figure 11-1 a panel proceeding's time clock only starts as of the composition of the panel. In addition, more time has also been required before that, more specifically, between panel establishment and panel composition. This is due to increasing amounts of time taken to agree on the appointment of panelists or for the WTO Director-General to appoint panelists which is increasingly the case, overall in $64 \%$ of panels. ${ }^{52}$ For example, in China - Domestic Support for Agricultural Products, it took the parties 180 days or half a year to agree on the composition of the panel (even though 20 days after the establishment of the panel, either party could have asked the Director-General to appoint the panel). ${ }^{53}$ Also the time lapse between issuance of a panel's report to the parties and circulation of the report to all WTO Members has significantly increased. During this period, the panel report is translated into the other two official languages of the WTO (mostly, from English to French and Spanish). For panel reports issued in the first 5 years (1996-2000), it only took on average 35 days to translate the report. During the last five years, it took on average 102 days. This almost tripling of translation periods closely correlates with increasingly long panel (and also $\mathrm{AB}$ ) reports over time. ${ }^{54}$

Figure 11-3: Translation period of panel reports issued by year

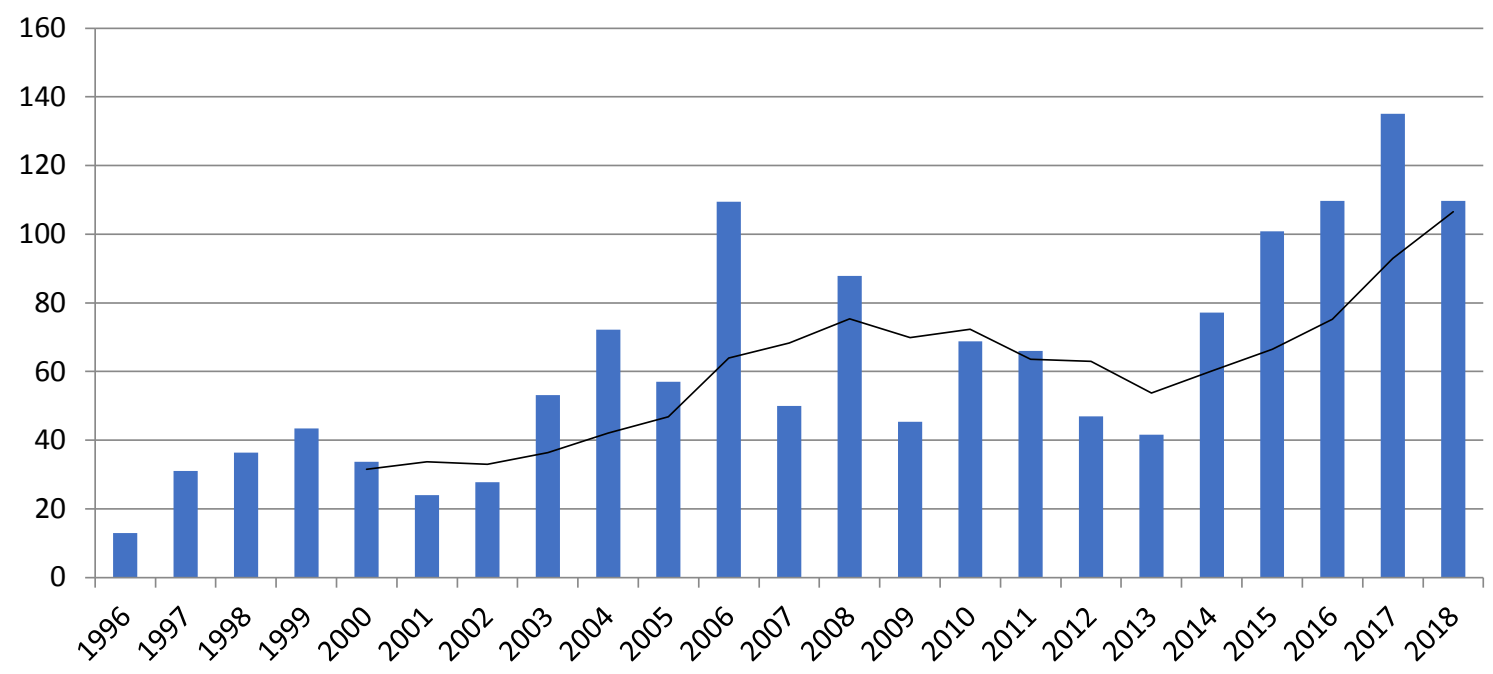

Most importantly, as noted in the introduction, since the end of 2014 there has been a significant backlog in almost all panel proceedings in trade remedy disputes due to the

\footnotetext{
52 Joost Pauwelyn, The Rule of Law Without the Rule of Lawyers? Why Investment Arbitrators are from Mars, Trade Adjudicators from Venus, 109 AJIL 761, 761 (2015), 785.

${ }^{53}$ See WTO website: https://www.wto.org/english/tratop_e/dispu_e/cases_e/ds511_e.htm (last visited 30 April 2018). The Panel was established on 16 December 2016, but was not composed until 24 June 2017.

${ }^{54}$ For the increase in length of AB reports, see Pauwelyn above n. 25.
} 
workload in the WTO Secretariat, in particular, the Rules Division dealing with trade remedy disputes. Communications from the panel were issued in 9 such disputes, citing the "lack of experienced lawyers in the secretariat" as the reason for the delay in the proceedings. ${ }^{55}$ A similar "queue" of cases awaiting consideration, reportedly due to lack of human resources (both $\mathrm{AB}$ Secretariat staff and $\mathrm{ABMs}$ ), has emerged in $\mathrm{AB}$ proceedings, as discussed in Section 2 above, where major delays are now common especially between the submission of party briefs and the date of the $\mathrm{AB}$ hearing. ${ }^{56}$ In response to this challenge, the WTO Secretariat recruited more legal support staff to assist panels and the Appellate Body, especially after 2015 (see Figures 3.1 and 3.2 above).

As fewer new cases are filed (see Figure 4 above) and, more importantly, pending cases take more time to complete (be it because of increased complexity, party-driven delays, the lack of support staff in the WTO Secretariat or because of vacant seats on the AB), output reflected by the number of circulated panel and $\mathrm{AB}$ reports - has dropped from its peak at the turn of the century (26 panel reports and 13 AB reports in 2000) to "only" 13 panel reports and 6 Appellate Body reports in 2017.

Figure 12: Panel and $A B$ reports issued per year

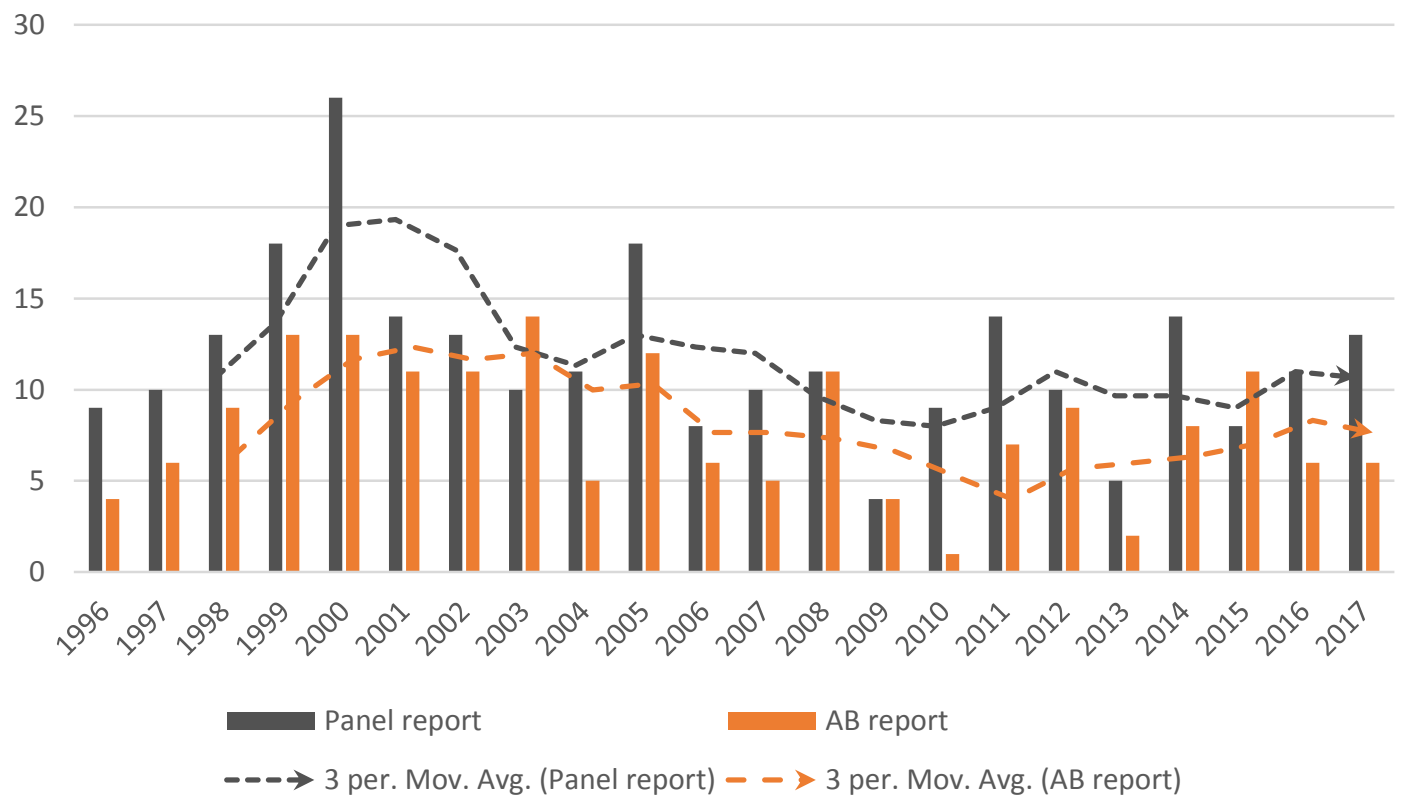

\footnotetext{
55 These disputes are : DS480, DS482, DS483, DS 486, DS 488, DS 490, DS 491, DS 496, DS 505

${ }^{56}$ See foonote 28 above.
} 


\section{Forecast of Panel and AB Caseload Post-2018}

At the cut-off date for this paper (30 April 2018), there were 14 pending original panel proceedings, 4 pending compliance panel proceedings (each time counting only panels actually composed) and 8 pending $\mathrm{AB}$ proceedings (of which 4 are appeals against DSU Article 21.5 compliance panels). ${ }^{57}$ In this Section, we attempt to forecast the panel and AB caseload beyond April 2018.

We first forecast how long it will take for the current caseload to phase out, assuming no new panel will be composed, and no new appeal will be notified, after April 2018. In doing so, we apply the following assumptions:

(i) Pending original panel proceedings: 10 of the 14 ongoing panels have issued a communication to indicate by when they plan to issue their report to the parties. To forecast the subsequent date of circulation of the report to all WTO Members, we add 120 days (the average number of days between issuance and circulation of panel reports circulated between January 2016 and April 2018). For the remaining 4 cases where there is no panel communication on the expected date of issuance, we add 659 days to the date of panel composition to obtain the forecast date of report circulation (the average number of days between panel composition and panel report circulation for panel reports issued between January 2016 and April 2018). ${ }^{58}$

(ii) Pending DSU Article 21.5 panel proceedings: panels in 3 of the 4 DSU Article 21.5 proceedings have indicated an estimated time for the issuance of their report. As above, we add another 120 days to forecast the circulation date. For the remaining case in which the panel has not indicated the expected time of issuance of its report, we apply 496 days between panel composition and report circulation (the average number of days used by DSU Article 21.5 panels which have circulated their report between January 2015 and April 2018). ${ }^{59}$

\footnotetext{
${ }^{57}$ Pending original panel proceedings are DS435, 441, 458, and 467; DS476; DS493; DS499; DS505; DS510; DS511; DS512; DS513; DS516; DS517; DS518; DS522; DS523. Pending DSU Article 21.5 panel proceedings: DS437; DS430; DS456; DS461. Pending AB proceedings: DS 316 (the AB report was issued to the parties on 25 April 2018); DS353; DS437; DS486; DS490 and 496; DS472 and 497; DS381; and DS495. The 4 appeals against DSU Article 21.5 compliance panels are DS316, DS353, DS437 and DS381.

${ }^{58}$ DS510, DS517, DS518, DS522.

${ }^{59}$ DS 456.
} 
(iii) Pending $\mathrm{AB}$ proceedings: As mentioned in the introduction, there is no indication from the $\mathrm{AB}$ on when these proceedings will be completed. Given the recent spike in the length of $\mathrm{AB}$ proceedings, we base our estimates on the average time of $\mathrm{AB}$ proceedings for $\mathrm{AB}$ reports circulated between January 2017 and April 2018 (257 days). For the long-running Boeing/Airbus disputes (DS316 and DS353, both of which are DSU Article 21.5 compliance cases), as they are outliers in the system taking exceptionally long periods of time, we apply a different method. The AB report in DS316 was issued to the parties on 25 April 2018; we add 20 days $^{60}$ to arrive at an expected date of circulation of 15 May 2018, that is, 579 days after the notice of appeal was filed in that dispute. For the AB report in DS353 we add the same number of days (579) to the notice of appeal in that case, to arrive at an expected date of circulation of the $\mathrm{AB}$ report of 29 January $2019 .^{61}$

On this basis, we forecast that all pending panel proceedings will be completed by the end of 2019 and all pending AB proceedings will be completed by January 2019, as illustrated in Figure 13. Once again, this forecast assumes that no new panels are composed, and no new appeals are filed, after April 2018. Notice that this forecast is rather optimistic, using relatively conservative timeframes given today's stress on the system (i.e. we assume that panels will actually stick to their announced date of issuance of reports, and that panel/AB time periods will not further increase as compared to the average of the last couple of years).

\footnotetext{
${ }^{60} \mathrm{AB}$ Reports are usually circulated on the same day as it is provided to the participants in the dispute. However, in cases such as DS316 and DS353 in which business confidential information (BCI) may be involved, the AB Division often provides a confidential advance copy to the participants in the dispute to ensure no such information has been inadvertently included. In DS487, it took 7 days between a confidential advance copy of the $\mathrm{AB}$ Report was provided to the participants and the final circulation of that report. In DS316, an advance copy of the AB report was circulated to the participants on 25 April 2018. At the cut-off date for this paper, the report was not circulated. We assume this report will be circulated relatively soon, on 15 May 2018, 20 days after the advance copy was shared with the participants.

${ }^{61}$ In DS316, the interval between the notice of appeal and the expected date circulation of the AB report is 579 days. In DS353, the notice of appeal was filed on 29 June 2016 . We thus add 579 days to the date of the notice of appeal to arrive at an estimate date of circulation of the AB report on 29 January 2019.
} 
Figure 13: Expected end-date of panel/AB proceedings pending on 30 April 2018

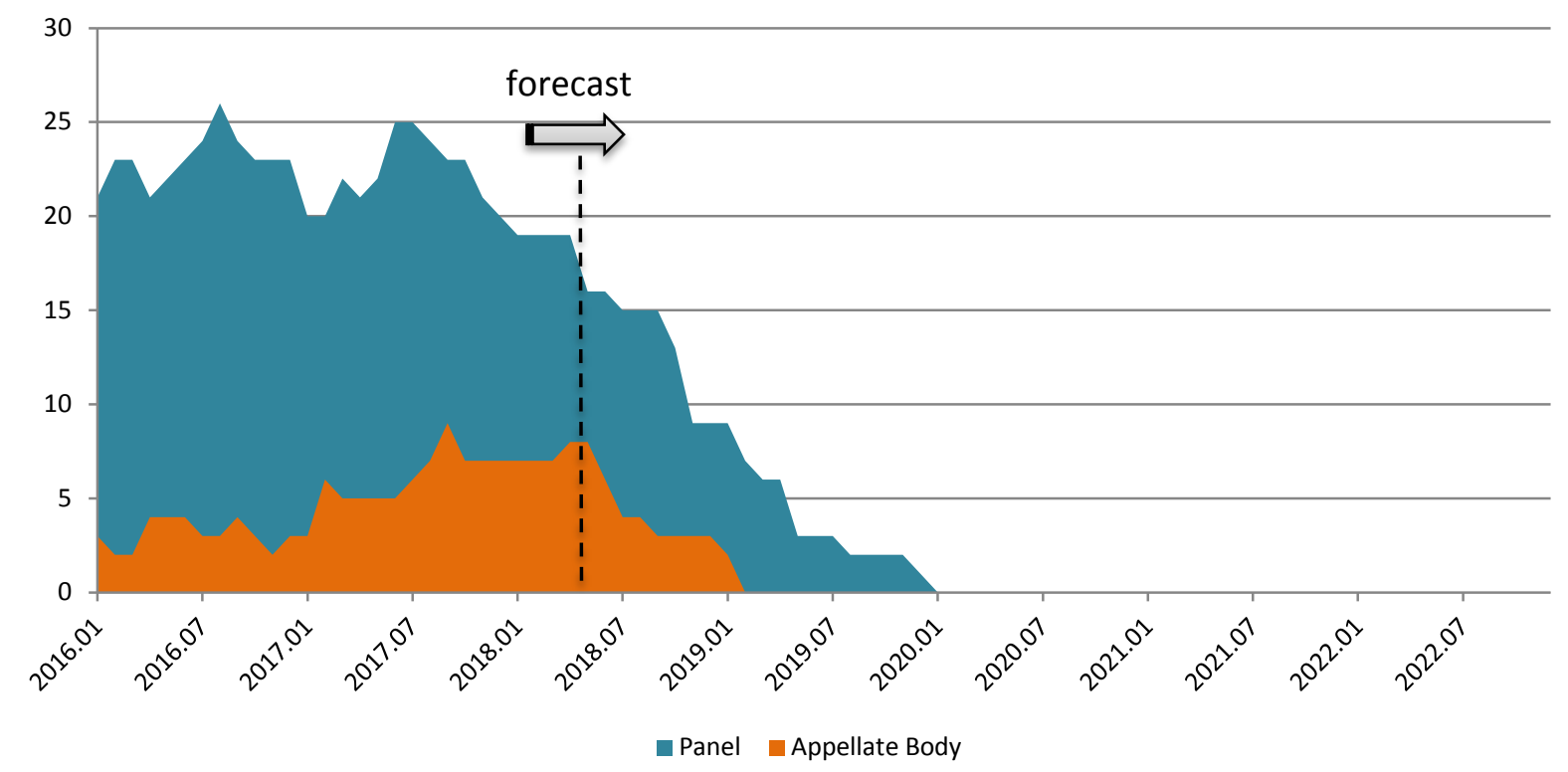

In a second step, we forecast caseload up to 10 years from now, taking into account not only pending proceedings but also new proceedings. Here we use the following assumptions:

(i) Disputes for which a panel was already established but not yet composed (11 cases): ${ }^{62} 6$ cases have exceeded the longest duration to compose a panel of panels composed since January 2016 (286 days) and thus we assume these cases will not proceed to panel composition. In DS526 a panel was established on 22 November 2017 but has not been composed so far after 159 days. Since it has exceeded the average time between panel establishment and composition of panels composed between January 2016 and April 2018 (118 days), we assume it will be composed after 286 days (the maximum for panels composed since 2016) on 4 September 2018. For the 2 remaining panels established most recently (DS436 and DS529), we add the average of 118 days to arrive at the date of panel composition.

(ii) Disputes for which a consultation request was filed yet no panel request has been made: as mentioned in Section 5, on average $75 \%$ of consultation requests moved to the panel stage in the last five years. Thus, for each dispute, we apply a coefficient of 0.75 .

${ }^{62}$ DS421; DS423; DS462; DS474; DS489; DS494; DS502; DS508; and DS526. 
(iii) New consultation requests: we assume that WTO Members will bring new disputes at the (fixed) rate of 16 disputes per year (the average of 2013-2017). Here as well we assume that $75 \%$ of new consultation requests will move to the panel stage.

(iv) Appeals: as mentioned in Section 8, the overall appeal rate since the AB's creation is $68 \%$. Thus, for all the panel reports we forecast, we assign a $68 \%$ likelihood of appeal.

Figure 14-1 illustrates what the future panel and $A B$ caseload will likely be if the dispute settlement system does "business as usual". For "business as usual", we apply the average number of days taken for panel and AB reports issued between January 2016 and April 2018 (210 days from consultation request to panel composition; 659 days from panel composition to circulation of panel report; and 257 days from notice of appeal to circulation of $\mathrm{AB}$ report). ${ }^{63}$ In this "business as usual" scenario, panel caseload will first drop to a relative low in the second half of 2018 (of "only" 13 to 18 panels), as a handful of pending panel proceedings are expected to conclude by then (see Figure 13) and $71 \%$ of cases filed in 2016 have already moved to panel composition. As the majority of disputes initiated in 2017 and 2018 may start to kick in in 2019, the caseload will steadily rise again as of 2019 to peak in 2020 at an all-time (monthly) high of 36 pending panel proceedings, after which it will once again decline to 21 or 22 as of mid 2022, that is, the numbers witnessed in 2016. As our forecast assumes a fixed rate of new cases (as well as fixed rates of advancement from consultations to panel stage and a fixed appeal rate), as of 2022, the forecast shows an almost straight line of 21-22 pending panels. This is considerably higher than the average so far (12, between 1995-2017); at the same time, it is similar to what the system experienced recently between 2014-2018 (average of 21). AB caseload will follow the pattern of movement of the panel caseload, only with some delay. After an initial drop beginning from the second half of 2019, it will markedly increase as of late 2020, to reach an all-time high in 2021 and 2022 of 10 to 11 pending appeals after which it will remain relatively stable at around 7 appeals as of 2023 (that is, close to and even slightly lower than the current $8 \mathrm{AB}$ proceedings pending). Here as well, the forecast indicates that even if we may see a brief drop in caseload in the immediate future, "the worst is still to come" (for the AB, the period between 2021-2022; for panels, between 2020-2021). Yet, even under a

\footnotetext{
${ }^{63}$ We also assume that WTO Members take 60 days to make a decision whether or not to appeal.
} 
"business as usual" scenario, things will improve and caseload will fall back as of 2022/2023 to panel and AB numbers that remain relatively high (respectively, 21-22 for panels and 6-7 for the $\mathrm{AB}$ ) but that we have already witnessed in recent years.

Figure 14-1: Scenario 1: "Business As Usual”

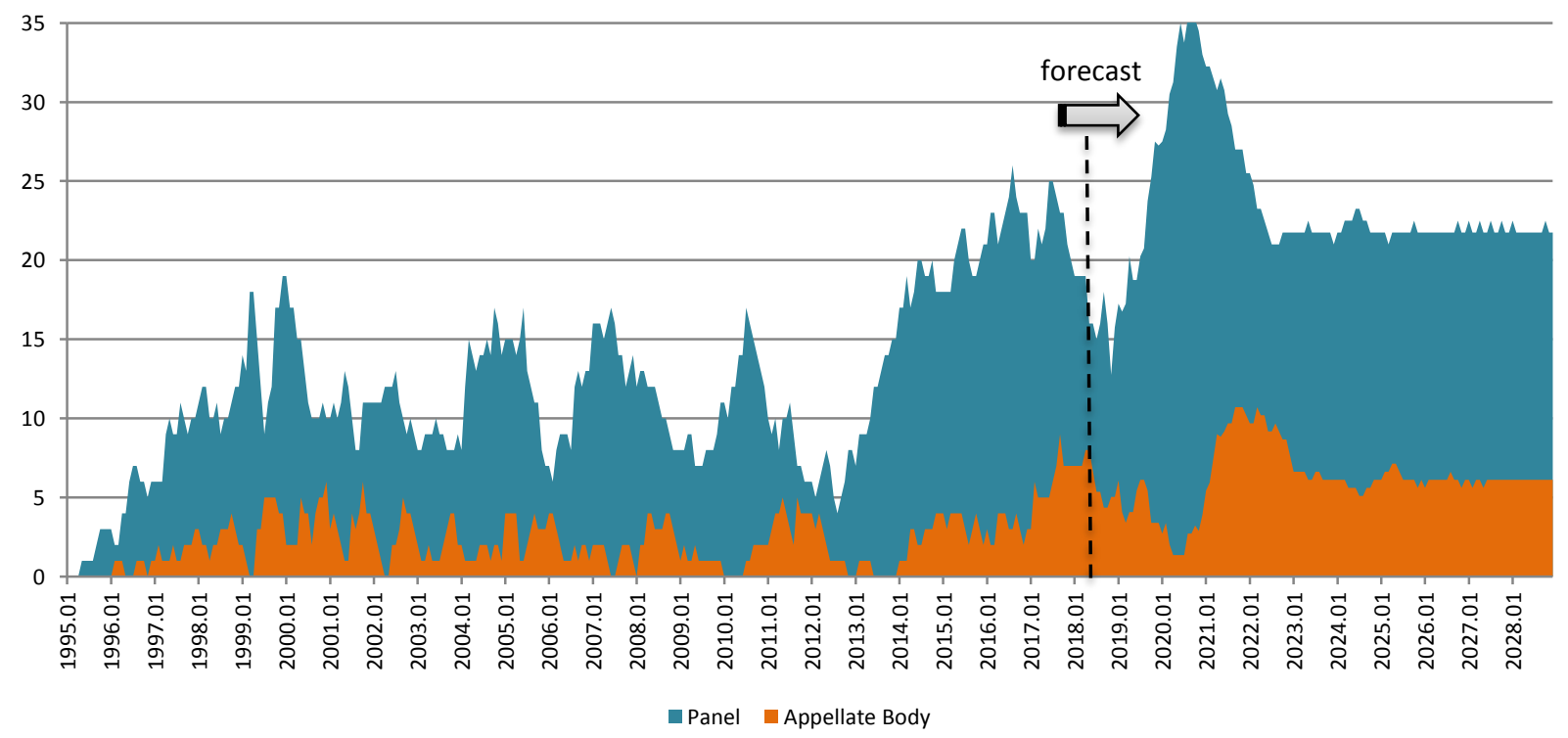

Figure 14-2: Scenario 2: "Back to Normal"

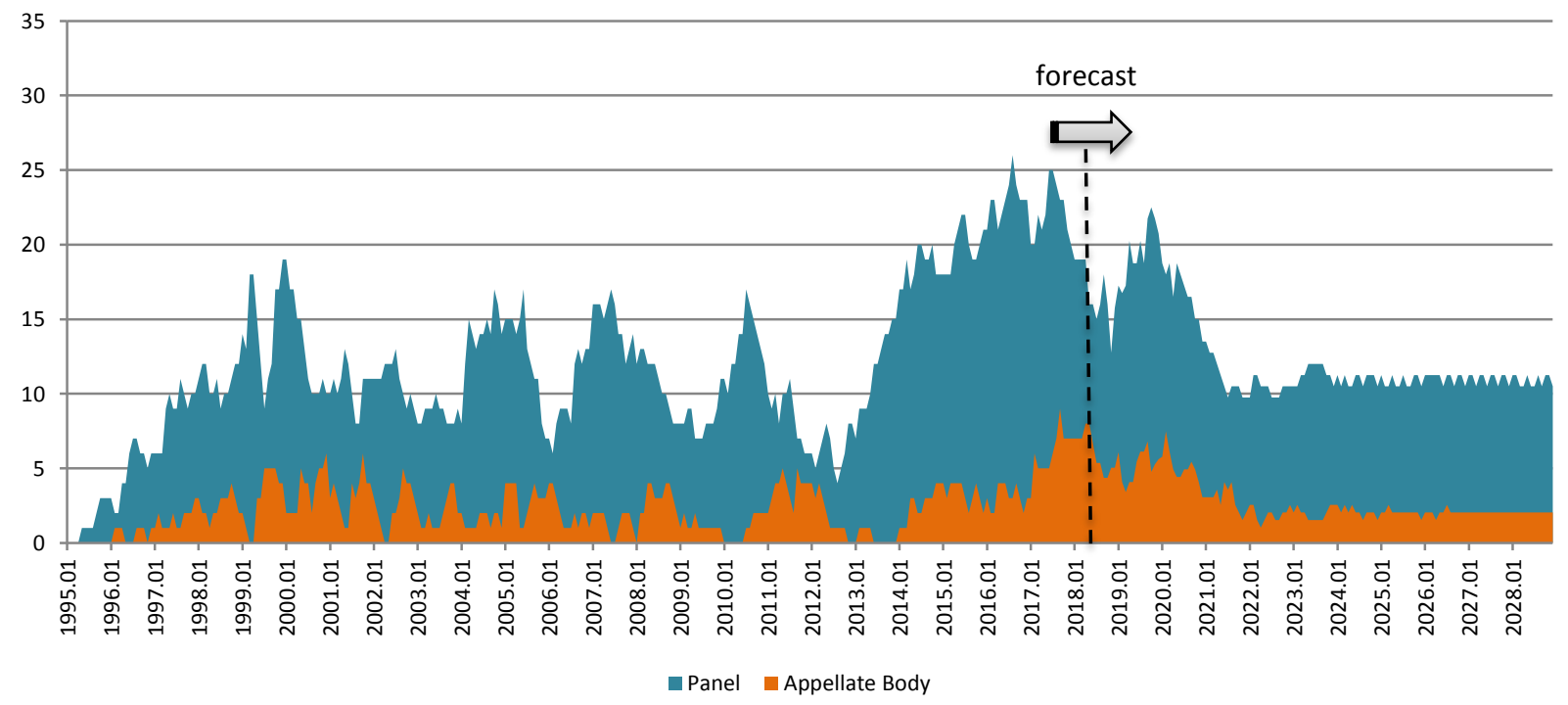

Figure 14-2 shows an alternative scenario ("back to normal”), more specifically, one that assumes that (i) panels composed after April 2018 can circulate their reports more quickly, namely, in the average time it took panels during the first ten years of the DSU (316 days) and (ii) the $\mathrm{AB}$ is able again to stick to its DSU-prescribed deadline of 90 days. On these assumptions, WTO caseload at the panel stage will drop to 17-19 concurrent proceedings as 
of 2020, a return to pre-2015 levels (and also around the level of panel cases pending today, 18). The AB, in turn, would experience no more than 5 concurrent proceedings from April 2020, less than the 8 pending today and similar to the caseload in 2016. Caseload would eventually stabilize at 10-12 concurrent proceedings for panels as of mid-2021 (as opposed to 21-22 as of mid-2022 in the "business as usual" scenario), and 2-3 concurrent appeals for the $\mathrm{AB}$ as of late 2021 (as opposed to around 7 appeals as of 2023 in the "business as usual" scenario).

Figure 14-3: Scenario 3: "More Settlements, Less Appeals"

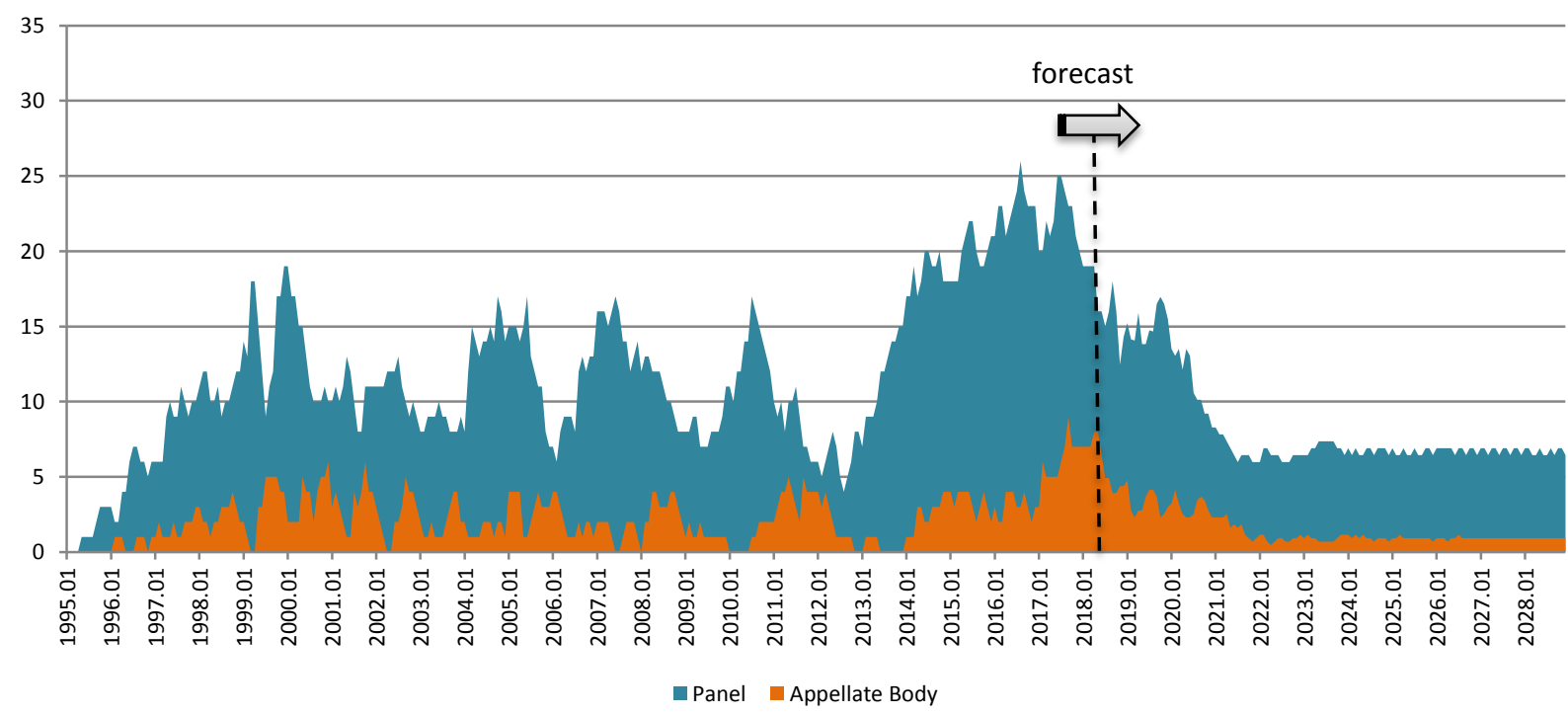

Caseload would be even lighter if WTO Members could, in addition, make better use of the consultation stage to settle their disputes and reduce the appeal rate. Figure 14-3 ("more settlements, less appeals") forecasts caseload on the assumption that (i) settlement rates would revert to what they were in the first ten years of the WTO (when only $46 \%$ of consultation requests moved to the panel stage) and (ii) the appeal rate would decline from $68 \%$ to $50 \%$ (the rate in the period between 2011-2013 as well as most recently in 2017). In this third scenario (which is otherwise based on "back to normal"), panel caseload would quickly drop to below 15 concurrent panels as of 2020 (the same as pre-2014 levels) and would be kept at the lower bound between six and seven from April 2021, that is, only about one third of the panel proceedings pending in April 2018 and half of the current average between 1995-2017 (which stands at 12). The last time panel caseload was limited to 6 cases dates back to 2012. AB caseload would also rapidly decline and reach no more than three concurrent proceedings from late 2020 onwards, that is, the 2014 level and far 
less than the current 8 . By 2021, AB proceedings would stabilize at around 1-2, similar to the overall average to date of 2 (between 1996-2017).

Table 3: Forecast summary table (yearly averages)

\begin{tabular}{|c|l|r|r|r|r|r|r|r|}
\hline \multicolumn{2}{|c|}{ Year } & 2019 & 2020 & 2021 & 2022 & 2023 & 2024 & $\begin{array}{r}\text { April } \\
2018\end{array}$ \\
\hline \multirow{3}{*}{ Panel } & Business as usual & 21 & 33 & 29 & 22 & 22 & 22 & 18 \\
\cline { 2 - 9 } & Back to normal & 20 & 17 & 11 & 10 & 11 & 11 & \\
\cline { 2 - 9 } & $\begin{array}{l}\text { More settlements, } \\
\text { less appeals }\end{array}$ & 15 & 11 & 7 & 6 & 7 & 7 & \\
\hline \multirow{3}{*}{$\begin{array}{c}\text { Appellate } \\
\text { Body }\end{array}$} & Business as usual & 5 & 2 & 9 & 9 & 6 & 6 & 8 \\
\cline { 2 - 8 } & Back to normal & 5 & 5 & 3 & 2 & 2 & 2 \\
\cline { 2 - 8 } & $\begin{array}{l}\text { More settlements, } \\
\text { less appeals }\end{array}$ & 3 & 3 & 2 & 1 & 1 & 1 & \\
\hline
\end{tabular}

\section{Conclusion}

Is the WTO dispute settlement system "busier than ever" and "a victim of its own success"? Yes and no. Yes, if one considers the recent numbers of cases pending before panels or the AB. No, if one looks at the number of new WTO disputes filed or the number of panel and $\mathrm{AB}$ reports issued yearly.

WTO dispute settlement does, indeed, currently experience a peak in terms of the total number of cases pending before panels and the AB. However, this is not due to an increase in new cases filed, but rather because pending cases take much longer to conclude as they have become more complex and are often delayed for lack of human resources. In addition, fewer cases filed get formally settled, appeal rates remain very high, and the share of follow-up disputes over compliance has increased, all three factors leading to more (pending) caseload without actually more (new) cases filed or more panel or AB reports issued per year. WTO dispute settlement is also predominantly used for certain types of disputes (in particular trade remedy cases) and disputes between a small subset of WTO Members. Measuring "success" of the system therefore varies depending on the angle taken. More cases are pending than ever, the system is attracting especially trade remedy disputes and the WTO Secretariat has more than doubled its legal support staff assisting panels and the AB. At the same time, fewer new cases are filed, fewer disputes achieve the preferred goal of settlement, cases take increasingly longer to wind their way through the system (with no retroactive remedies as a backstop), appeal rates remain high, the need for 
panels to decide compliance disputes has increased and fewer panel and $\mathrm{AB}$ reports are issued per year.

Looking forward, we forecast that the current glut in WTO caseload will not last. More specifically, after a temporary drop in 2019, we forecast a record-breaking spike in 20202022, after which WTO caseload will fall back and stabilize at numbers we have seen before. In none of the three scenarios we set out ("business as usual", "back to normal", "more settlements, less appeals") is there reason to panic today (e.g. to massively hire additional, long-term WTO Secretariat staff; temporary hires to address the 2020-2022 spike would suffice). Moreover, relatively small improvements -- panels and the $A B$ renewing compliance with timeframes set out in the DSU; the system improving on its "clearly preferred" solution of settlement, and parties exercising restraint when it comes to appealing panel reports (the assumptions under our "more settlements, less appeals scenario") -- would bring WTO caseload down to surprisingly low levels (post-2021: 6-7 concurrent panels, and 1-2 concurrent $\mathrm{AB}$ proceedings). But there is also a "worst case scenario": if WTO Members continue to fail to fill vacancies on the Appellate Body, WTO dispute settlement will grind to a halt in December 2019, at which time only 1 individual would remain on the $\mathrm{AB}$, making it impossible for the $\mathrm{AB}$ to function. 